\title{
PRODUÇÃO ANTECIPADA DE PROVA OU AÇÃO AUTÔNOMA DE EXIBIÇÃO DE DOCUMENTO: A CONTROVÉRSIA SOBRE A PROVA DOCUMENTAL NO $\mathrm{CPC} / \mathbf{2 0 1 5}^{1}$
}

\author{
ANTICIPATED PRODUCTION OF PROOF OR AUTONOMOUS ACTION OF \\ DOCUMENT EXHIBITION: THE CONTROVERSY ON THE DOCUMENTARY \\ PROOF AT CPC/2015
}

Giovanni Vidal Guaragni

Mestrando em Direito pela Pontifícia Universidade Católica do Paraná (PUCPR). Especialista em Direito Contemporâneo com ênfase no NCPC, pela Universidade Cândido Mendes. Licenciado em Filosofia, pela Pontifícia Universidade Católica do Paraná (PUCPR); bacharel em Direito, pela Universidade Federal do Paraná (UFPR). Curitiba/PR. Email: giovan.v.g@hotmail.com

Sandro Marcelo Kozikoski Mestre e Doutor em Direito das Relações Sociais pela Universidade Federal do Paraná (UFPR). Professor Adjunto de Direito Processual Civil da Universidade Federal do Paraná (UFPR). Ex-Professor Adjunto da Faculdade Nacional de Direito (FND) - UFRJ. Coordenador Científico e Professor do Curso de Especialização em Direito Processual Civil da Academia Brasileira de Direito Constitucional (ABDConst). Ex-integrante da Comissão de Estudos Constitucionais da Ordem dos Advogados do Brasil, Seção Paraná (OAB/PR). Professor do Curso de Especialização em Direito Processual do Instituto Romeu Felipe Bacellar. Membro do Instituto dos Advogados do Paraná (IAP), do

\footnotetext{
${ }^{1}$ Artigo recebido em 23/02/2019 e aprovado em 29/07/2019.
} 
Revista Eletrônica de Direito Processual - REDP.

Rio de Janeiro. Ano 13. Volume 20. Número 3. Setembro a Dezembro de 2019

Periódico Quadrimestral da Pós-Graduação Stricto Sensu em Direito Processual da UERJ

Patrono: José Carlos Barbosa Moreira (in mem.). ISSN 1982-7636. pp. 145-186 www.redp.uerj.br

Instituto Brasileiro de Direito Processual (IBDP) e do Comitê

Brasileiro de Arbitragem (CBAr). Ex-Procurador Geral do Estado do Paraná - PGE (2018). Curitiba/PR. E-mail: sandro@akmps.adv.br

RESUMO: O intuito do presente artigo é auxiliar na solução de algumas controvérsias doutrinárias que vêm repercutindo na jurisprudência, sobre a possibilidade ou não de se ajuizar uma demanda autônoma de exibição de documento a partir da vigência do $\mathrm{CPC} / 2015$, que extinguiu as cautelares nominadas presentes no $\mathrm{CPC} / 73$ e instituiu o procedimento de produção antecipada de prova, entendido como a atual consagração do direito à prova. Partindo de uma análise dos institutos do CPC/73 e passando pelas bases principiológicas da reforma operada pelo CPC/2015, distinguem-se três teorias sobre a temática principal da pesquisa: (i) a teoria incidental; (ii) a teoria autônoma; e (iii) a teoria autônoma diferenciada. Defendendo-se a teoria autônoma, sustenta-se ser possível a exibição de documento por meio de demanda autônoma de exibição, desvinculada do rito especial da ação de produção antecipada de provas, prevista nos artigos 381 a 383, do CPC. A produção antecipada de prova documental, assim, pode se dar por três vias: (i) em procedimento cautelar de caráter antecedente (art. 305, do CPC); (ii) em ação de produção antecipada de provas; e (iii) em ação autônoma de exibição de documento, devendo-se atentar à fungibilidade entre os institutos, quando possível e adequado ao resultado útil do processo.

PALAVRAS-CHAVE: processo civil; prova documental; produção antecipada de prova; ação autônoma de exibição; teoria autônoma.

ABSTRACT: The purpose of this article is to help solve some doctrinal controversies that have been reverberating in the jurisprudence, on whether or not to demand an autonomous request for the exhibition of a document after the validity of CPC/2015, which extinguished the nominee precautionary measures of CPC/73 and instituted the procedure for the anticipated production of proofs, understood as the current consecration of the right to proof. Starting from an analysis of the CPC/73 institutes and passing through the principiological bases of the CPC/2015 reform, three theories about the main theme of the 
research are presented: (i) the incidental theory; (ii) the autonomous theory; and (iii) differentiated autonomous theory. Defending the autonomous theory, it is maintained that it is possible the presentation of a document by an autonomous demand for exhibition, unrelated to the special rite of the anticipated production of proofs, provided on articles 381 to 383 of the CPC. The anticipated production of documentary evidence can thus take three forms: (i) in a precautionary procedure of an antecedent nature (article 305 of the CPC); (ii) in advance production of proofs; and (iii) in an autonomous document exhibition action, due regard being had to the fungibility among the institutes, when possible and adequate to the useful result of the process.

KEY WORDS: civil lawsuit; documental proof; anticipated production of proofs; autonomous exhibition action; autonomous theory.

\section{INTRODUÇÃO}

Qual o instrumento processual adequado à pretensão de exibição de documento ou coisa em posse da parte contrária? A resposta a essa questão se altera a depender da existência de ação de conhecimento em curso? Quais os critérios para identificar a existência de interesse processual? E se o pedido de exibição for urgente e necessário para assegurar o futuro êxito de uma demanda de conhecimento, voltada à realização de direito material? Quem será considerado sucumbente em demanda de caráter exibitório?

Esses são alguns questionamentos que a serem examinados no presente artigo. A pesquisa foi desenvolvida com o intuito de auxiliar na solução de algumas controvérsias doutrinárias que vêm repercutindo na jurisprudência, sobre a possibilidade ou não de se ajuizar uma demanda autônoma de exibição de documento a partir da vigência do CPC/2015, cuja estruturação das tutelas de urgência resultou na extinção das cautelares típicas presentes no $\mathrm{CPC} / 73$, sem embargo da instituição do procedimento de produção antecipada de prova, entendido como a atual consagração do direito à prova.

Nesse sentido, o presente ensaio principia pela análise do procedimento da exibição de documento ou coisa e das cautelares nominadas, tais como previstas no CPC/73. 
Rio de Janeiro. Ano 13. Volume 20. Número 3. Setembro a Dezembro de 2019

Periódico Quadrimestral da Pós-Graduação Stricto Sensu em Direito Processual da UERJ

Patrono: José Carlos Barbosa Moreira (in mem.). ISSN 1982-7636. pp. 145-186 www.redp.uerj.br

No item seguinte, examinam-se, brevemente, os requisitos consolidados pela jurisprudência voltados à verificação do interesse de agir da parte postulante que ajuizava medida cautelar de exibição, na vigência do antigo código.

A partir do terceiro item, o estudo se volta ao exame e ambientação do novo código, primeiramente realizando uma abordagem principiológica, na tentativa de demonstrar a guinada em prol dos princípios e valores constitucionais assumida pelo CPC/2015, envolvendo a mudança de uma perspectiva formalista e procedimentalista, para uma ideia de processo comprometido com a efetividade e a resolução do conflito.

$\mathrm{O}$ item quatro trabalha com a produção antecipada de provas no $\mathrm{CPC} / 2015$, enquanto o tópico subsequente (cinco) aborda o instituto da exibição de documento ou coisa.

Tudo isso com o objetivo de fixar as premissas hábeis a dirimir o conflito examinado no item seis, entre os dois institutos previamente expostos, no que tange à possibilidade ou não de ajuizamento de uma ação autônoma de exibição, desvinculada do rito especial previsto pelos dispositivos legais que regulam a produção antecipada de provas.

Espera-se que o presente texto contribua para o debate doutrinário, no intuito de aprimorar os institutos processuais civis vigentes.

\section{A EXIBIÇÃ̃o DE DOCUMENTO OU COISA (ARTIGOS 355 A 363) E AS CAUTELARES NOMINADAS DE EXIBIÇÃO E PRODUÇÃO ANTECIPADA DE PROVAS (ARTIGOS 844 A 851) NO CPC/73.}

$\mathrm{O}$ documento é considerado a fonte da prova documental, de onde se extraem informações sobre um fato ou ato nele representado. A prova documental, por seu turno, é o instrumento por meio do qual a fonte é "levada ao processo para análise judicial; é a ponte entre o fato e a mente do juiz"

O regramento processual brasileiro prevê distintas formas de obtenção das provas documentais, que não se resumem às provas escritas, uma vez que existe "prova documental não escrita (p. ex., a fotografia) do mesmo modo que há prova escrita não documental (p. ex., o laudo pericial)"’3.

Via de regra, a maioria das provas documentais presentes no processo são trazidas pelas partes, em petição inicial e contestação, no intuito de, prontamente, conferir

${ }^{2}$ DIDIER JR., Fredie. Curso de direito processual civil: teoria da prova, direito probatório, decisão, precedente, coisa julgada e tutela provisória. Salvador: Ed. Jus Podivm, 2018, p. 209.

${ }^{3}$ Ibidem, p. 208. 
Revista Eletrônica de Direito Processual - REDP.

Rio de Janeiro. Ano 13. Volume 20. Número 3. Setembro a Dezembro de 2019

Periódico Quadrimestral da Pós-Graduação Stricto Sensu em Direito Processual da UERJ

Patrono: José Carlos Barbosa Moreira (in mem.). ISSN 1982-7636. pp. 145-186 www.redp.uerj.br

sustentação e verossimilhança às suas alegações. Aos casos em que a parte, entretanto, não possuía acesso ao documento que desejava juntar aos autos, o Código de Processo Civil de 1973 (CPC/73) previa duas figuras essenciais: (i) a exibição de documento ou coisa (arts. 355 a 363) e (ii) a medida cautelar de exibição (arts. 844-845).

O mecanismo da (i) exibição de documento ou coisa, então contemplado no CPC/73, era regido pelos artigos 355 a 363 e pressupunha a existência de processo de conhecimento em andamento ${ }^{4}$. Quando a pretensão de exibição era movida em face da contraparte, não ensejava nova relação autônoma, mas somente um incidente processual ${ }^{5}$, cuja decisão final (art. 359, CPC/73) se sujeitava a recurso de agravo ${ }^{6}$.

Quando o alvo da ordem de exibição era um terceiro (art. 360, CPC/73), uma nova relação processual surgia, em procedimento que, apensado ao processo principal, seguia o rito comum ordinário, sendo extinto por sentença judicial e, malgrado algumas polêmicas, era impugnável pela via do recurso de apelação.

A exibição poderia, ainda, ser ordenada ex officio pelo magistrado com fulcro no artigo 130, do CPC/73, ao dispor que incumbia "ao juiz, de ofício ou a requerimento da parte, determinar as provas necessárias à instrução do processo, indeferindo as diligências inúteis ou meramente protelatórias".

Nas hipóteses em que a obtenção de uma prova consistia necessidade urgente e irremediável, porém não havia processo de conhecimento em curso (requisito imprescindível, à época, à aplicação dos artigos 355 a 363), apelava-se às medidas cautelares probatórias nominadas, então elencadas em quatro diferentes espécies: (i) a exibição (arts. 844-845); (ii) a produção antecipada de provas (arts. 846-851); (iii) o arrolamento de bens (arts. 855-860); e (iv) a justificação (arts. 861-866).

Consoante digressão histórica que não comporta exame nas vias estreitas do presente trabalho, as medidas cautelares possuem caráter protetivo em relação a uma determinada situação material ou processual, exigindo-se, para seu acatamento, a demonstração de urgência (periculum in mora) do provimento requerido.

A natureza cautelar das ações probatórias era objeto de discussões doutrinárias incessantes. Parte dos estudiosos afirmava que a cautelaridade destas ações se demonstrava

\footnotetext{
${ }^{4}$ MARINONI, Luiz Guilherme; MITIDIERO, Daniel. Código de processo civil comentado artigo por artigo.São Paulo: Editora Revista dos Tribunais, 2008, p. 357.

5 Ibidem, p. 359.

${ }^{6}$ Ibidem, p. 361.
} 
Revista Eletrônica de Direito Processual - REDP.

Rio de Janeiro. Ano 13. Volume 20. Número 3. Setembro a Dezembro de 2019

Periódico Quadrimestral da Pós-Graduação Stricto Sensu em Direito Processual da UERJ

Patrono: José Carlos Barbosa Moreira (in mem.). ISSN 1982-7636. pp. 145-186

www.redp.uerj.br

somente em termos procedimentais, em detrimento do conteúdo e propósito da medida pleiteada, visto que visavam assegurar situações processuais e condições propícias ao exercício do direito de ação ${ }^{7}$, enquanto as demais cautelares resguardavam "o interesse substancial, entendido como núcleo da situação subjetiva favorável"8.

Noutra senda, partindo de uma noção de processo como mero instrumento da jurisdição, entendia-se que sua proteção implicava, mesmo que indiretamente, a proteção do direito material, fim último do processo9 .

Deve-se observar que as cautelares probatórias nominadas somente se aplicavam quando havia perigo de que, pela demora, a produção da prova na fase própria do processo de conhecimento restasse inviabilizada ${ }^{10}$. Asseguravam, assim, "a prova a ser utilizada em processo de conhecimento, diante do risco de se perdê-la com o passar do tempo"11.

Nesse sentido, atribuir cautelaridade às medidas probatórias do $\mathrm{CPC} / 73$ revelava-se adequado, tendo em vista o intuito de assegurar o direito à prova - componente essencial do devido processo legal (art. $5^{\circ}$, inc. $\mathrm{LV}$, da $\mathrm{CF}$ ) - e, indiretamente e quando necessário, garantir o exercício proveitoso e frutífero do direito de ação (art. $5^{\circ}$, inc. XXXV, da CF) afinal, a despeito da ação como direito abstrato ao pronunciamento jurisdicional ${ }^{12}$, deve-se, ao máximo, evitar o ajuizamento de demandas temerárias, nas quais não haja substrato probatório suficiente ao esclarecimento dos fatos e, em razão disso, o julgamento de improcedência se baseie no mero desatendimento do ônus probatório.

Tratava-se de um propósito acautelatório, desvinculado de uma situação jurídica ou direito material a ser tutelado, mas diretamente relacionado à garantia de direitos processuais igualmente relevante, fundamentais à concretização de ulteriores pretensões materiais, ainda que extrajudicialmente.

\footnotetext{
${ }^{7}$ LAUX, Francisco de Mesquita. Relações entre a antecipação da prova sem o requisito da urgência e a construção de soluções autocompositivas. Revista de Processo, vol. 242/2015, p. 457 - 481,Abr / 2015, p. 03-04.

${ }^{8}$ GUIMARÃES, Filipe. Medidas probatórias autônomas: panorama atual, experiência estrangeira e as novas possibilidades no direito brasileiro. Revista de Processo, vol. 178/2009, p. 123 - 152, Dez / 2009, p. 02. ${ }^{9}$ OLIVEIRA, Thiago. A aplicação do art. 806 do CPC na ação cautelar de produção antecipada de prova. 56f. Brasília, 2008, Monografia (Especialização em Direito Processual Civil) - Curso de PósGraduação Lato Sensu do Instituto Brasiliense de Direito Público - IDP, p. 40.

${ }^{10}$ GUIMARÃES, Filipe. Medidas probatórias autônomas: panorama atual, experiência estrangeira e as novas possibilidades no direito brasileiro. Revista de Processo, vol. 178/2009, p. 123 - 152, Dez / 2009, p. 04.

${ }^{11}$ DIDIER JR., Fredie. Ações autônomas de produção de provas: produção antecipada de prova e justificação. Revista de processo, vol. 218/2013, p. 13-45, Abr/2013, p. 03.

${ }^{12}$ SCHIAVI, Mauro. Manual de direito processual do trabalho. São Paulo: LTr, 2016, p. 73.
} 
Revista Eletrônica de Direito Processual - REDP.

Rio de Janeiro. Ano 13. Volume 20. Número 3. Setembro a Dezembro de 2019

Periódico Quadrimestral da Pós-Graduação Stricto Sensu em Direito Processual da UERJ

Patrono: José Carlos Barbosa Moreira (in mem.). ISSN 1982-7636. pp. 145-186 www.redp.uerj.br

Partindo às duas espécies de medidas cautelares probatórias que serão analisadas, inicia-se pela cautelar de exibição (arts. 844-845, do CPC/73).

Diferentemente do procedimento incidental, a cautelar de exibição costumava ser usada em seu viés preparatório, ou seja, utilizada para o acesso e obtenção da prova documental, principalmente - em momento anterior à instauração do processo de conhecimento $^{13}$. A exibição (incidental ou preparatória) não tinha por finalidade imediata a tutela de um direito, mas "a preservação da autoridade jurisdicional e, mais precisamente, a proteção da utilidade do processo" $"$.

Nesse sentido:

Trata-se de tutela que visa à proteção do direito fundamental ao processo justo (art. $5^{\circ}$, LIV, CRFB), que tem como elementos indissociáveis o direito de ação (art. $5^{\circ}, \mathrm{XXXV}, \mathrm{CRFB}$ ), o direito de defesa (art. $5^{\circ}, \mathrm{LV}$, CRFB) e o direito à prova (art. $\left.5^{\circ}, \mathrm{LVI}, \mathrm{CRFB}\right)$. A exibição pode ser incidental (arts. 355 a 363, CPC) ou autônoma (art. 844 e 845, CPC). A exibição de que tratam os arts. 844 e 845 , CPC, é a exibição preparatória (autônoma). A finalidade da exibição é a proteção à prova - seu conhecimento e preservação ${ }^{15}$.

A segunda medida abordada é a produção antecipada de provas (arts. 846-851), que se limitava a assegurar provas pericial e oral ${ }^{16}$, não sendo útil, portanto, à prova documental. Tratava-se de um processo cautelar, caracterizado por sua instrumentalidade "remédio prescrito para garantir a preservação de determinadas situações sem as quais restaria frustrado o provimento de mérito nos processos de conhecimento e de execução"17.

Assim como ocorria com a cautelar de exibição, era necessária a demonstração do interesse da parte em assegurar a prova, não sendo exigido, entretanto, demonstrar o direito material correlato, futuramente sustentado. $\mathrm{O}$ traço comum às cautelares típicas e à exibição incidental no $\mathrm{CPC} / 73$ era o intuito de "assegurar a produção da prova enquanto

\footnotetext{
${ }^{13}$ MARINONI, Luiz Guilherme; MITIDIERO, Daniel. Código de processo civil comentado artigo por artigo. São Paulo: Editora Revista dos Tribunais, 2008, p. 357.

${ }^{14}$ ARENHART, S; MARINONI, L. Curso de processo civil: processo cautelar. São Paulo: Editora Revista dos Tribunais, 2008, p. 245.

${ }^{15}$ MARINONI, Luiz Guilherme; MITIDIERO, Daniel. Código de processo civil comentado artigo por artigo. São Paulo: Editora Revista dos Tribunais, 2008, p. 781.

${ }^{16}$ ROCHA, José de Moura. Produção antecipada de provas. Revista de Processo, vol. 20/1980, p. 56 - 65 , Out - Dez / 1980, Doutrinas Essenciais de Processo Civil, vol. 5, p. 819 - 830, Out / 2011, p. 01.

${ }^{17}$ GUIMARÃES, Filipe. Medidas probatórias autônomas: panorama atual, experiência estrangeira e as novas possibilidades no direito brasileiro. Revista de Processo, vol. 178/2009, p. 123 - 152, Dez / 2009, p. 02.
} 
Revista Eletrônica de Direito Processual - REDP.

Rio de Janeiro. Ano 13. Volume 20. Número 3. Setembro a Dezembro de 2019

Periódico Quadrimestral da Pós-Graduação Stricto Sensu em Direito Processual da UERJ

Patrono: José Carlos Barbosa Moreira (in mem.). ISSN 1982-7636. pp. 145-186 www.redp.uerj.br

meio (formação do convencimento do magistrado) destinado a consecução de um fim diverso (acolhimento/rejeição do pedido)" "18, vinculado à ulterior ação de conhecimento.

Contudo, antecipando a noção de um direito autônomo à prova e inovações que viriam a se concretizar somente no CPC atual, parte da doutrina já pontuava que, a despeito de normalmente subsidiar o exercício de um direito fundamental processual (ação ou defesa), havia casos em que o interesse do requerente se satisfaria na simples exibição ou asseguração da prova, e não teria por finalidade nenhuma demanda judicial posterior ${ }^{19}$. Com efeito, não se poderia descartar a circunstância de que, obtida a prova, aquele que a postulou poderia se convencer da inviabilidade de sua pretensão material.

Já na vigência do CPC/73, vislumbrava-se, com fulcro em ordenamentos jurídicos estrangeiros, a tendência da utilização de instrumentos destinados à colheita antecipada de provas, desvinculados do requisito do periculum in mora e justificados no conhecimento dos fatos pelas partes e consequente prevenção de litígios ${ }^{20}$. À época, já se apontava para uma paulatina desvinculação das ações probatórias em relação às ações de conhecimento, pois se compreendia apossível "satisfação dos anseios dos litigantes com a simples concessão da tutela nos autos de um processo cautelar"21.

O próprio Superior Tribunal de Justiça (STJ) entendia que as ações autônomas de exibição poderiam ser cautelares, visando proteger, garantir ou assegurar o resultado útil de um provimento jurisdicional ulterior, ou dotadas de caráter satisfativo, apresentadas como "demanda principal, visando apenas a exibição do documento ou coisa, apresentando cunho definitivo e podendo vir a ser preparatória de uma ação principal - a depender dos dados informados"22.

\section{O RECURSO ESPECIAL $\mathrm{N}^{\circ} 1.349 .453 / \mathrm{MS}$ E O ESTABELECIMENTO DE PARÂMETROS À VERIFICAÇÃO DO INTERESSE DE AGIR.}

Não obstante algum dissenso doutrinário, as condições de ação ou, mais

\footnotetext{
${ }^{18}$ LIPPMANN, Rafael Knorr. A "inédita" tutela do direito material (e autônomo) de acesso à prova. Disponível em: <http://www.emap.com.br/Nucleo\%20de\%20Pesquisas\%20Avancadas\%20da\%20EMAP/>. Acesso em: junho de 2018.

${ }^{19}$ ARENHART, S; MARINONI, L. Curso de processo civil: processo cautelar. São Paulo: Editora Revista dos Tribunais, 2008, p. 252.

${ }^{20}$ GUIMARÃES, Filipe. Medidas probatórias autônomas: panorama atual, experiência estrangeira e as novas possibilidades no direito brasileiro. Revista de Processo, vol. 178/2009, p. 123 - 152, Dez / 2009, p. 04.

${ }^{21}$ Ibidem, p. 05.

${ }^{22}$ REsp 1349453/MS, Rel. Ministro LUIS FELIPE SALOMÃO, SEGUNDA SEÇÃO, julgado em 10/12/2014, DJe 02/02/2015.
} 
Revista Eletrônica de Direito Processual - REDP.

Rio de Janeiro. Ano 13. Volume 20. Número 3. Setembro a Dezembro de 2019

Periódico Quadrimestral da Pós-Graduação Stricto Sensu em Direito Processual da UERJ

Patrono: José Carlos Barbosa Moreira (in mem.). ISSN 1982-7636. pp. 145-186

www.redp.uerj.br

acertadamente, os requisitos ao julgamento de mérito ${ }^{23}$ exigidos pelo CPC-73 eram três: (i)

possibilidade jurídica do pedido; (ii) legitimidade das partes; e (iii) interesse processual (arts. $3^{\circ}$ e 267 , do CPC/73).

No que tange, especificamente, à ação cautelar de exibição de documento, discutiuse muito sobre a existência ou não, em casos concretos, do interesse processual ou interesse de agir, subdividido na tríade (i) necessidade, (ii) utilidade e (iii) adequação.Entendia a doutrina que a resistência da parte adversa a uma pretensão probatória é que fazia"surgir o interesse-necessidade, impondo-se a intervenção e atuação do Estado-juiz para que assegure que a prova seja produzida democraticamente em juízo"24.

Ao menos no tocante à pretensão de exibição de documentos bancários, a jurisprudência foi pacificada na forma do precedente extraído do REsp $n^{\circ}$ 1.349.453/MS, julgado pelo Superior Tribunal de Justiça (STJ), em que foram estabelecidos os requisitos ao reconhecimento do interesse processual do demandante, quais sejam: (i) a existência de relação jurídica entre as partes; (ii) a comprovação de prévio pedido à instituição financeira não atendido em prazo razoável (pretensão resistida administrativamente); (iii) e o pagamento do custo do serviço conforme previsão contratual e normatização da autoridade monetária:

PROCESSO CIVIL. RECURSO ESPECIAL REPRESENTATIVO DE CONTROVÉRSIA. ART. 543-C DO CPC. EXPURGOS INFLACIONÁRIOS EM CADERNETA DE POUPANÇA. EXIBIÇÃO DE EXTRATOS BANCÁRIOS. AÇÃO CAUTELAR DE EXIBIÇÃO DE DOCUMENTOS. INTERESSE DE AGIR. PEDIDO PRÉVIO À INSTITUIÇÃO FINANCEIRA E PAGAMENTO DO CUSTO DO SERVIÇO. NECESSIDADE. 1. Para efeitos do art. 543-C do CPC, firma-se a seguinte tese: A propositura de ação cautelar de exibição de documentos bancários (cópias e segunda via de documentos) é cabível como medida preparatória a fim de instruir a ação principal, bastando a demonstração da existência de relação jurídica entre as partes, a comprovação de prévio pedido à instituição financeira não atendido em prazo razoável, e o pagamento do custo do serviço conforme previsão contratual e normatização da autoridade monetária. 2. No caso concreto,

\footnotetext{
23 "O interesse de agir e a legitimidade para causa representam requisitos para o julgamento do pedido (não podendo mais ser considerados, como já se propôs, elementos constitutivos da ação) e devem ser aferidos in status assertionis, isto é, à vista das afirmações do demandante, sem tomar em conta as provas produzidas no processo". In: MARINONI, Luiz Guilherme; MITIDIERO, Daniel. Código de Processo Civil comentado artigo por artigo. São Paulo. RT. 2008. p. 98.

${ }^{24}$ DIDIER JR., Fredie. Ações autônomas de produção de provas: produção antecipada de prova e justificação.
} Revista de processo, vol. 218/2013, p. 13-45, Abr/2013, p. 07. 
Revista Eletrônica de Direito Processual - REDP.

Rio de Janeiro. Ano 13. Volume 20. Número 3. Setembro a Dezembro de 2019

Periódico Quadrimestral da Pós-Graduação Stricto Sensu em Direito Processual da UERJ

Patrono: José Carlos Barbosa Moreira (in mem.). ISSN 1982-7636. pp. 145-186 www.redp.uerj.br

recurso especial provido. (REsp 1349453/MS, Rel. Ministro LUIS FELIPE SALOMÃO, SEGUNDA SEÇÃO, julgado em 10/12/2014, DJe 02/02/2015)

O julgamento, que no caso concreto abordava uma lide entre correntista e instituição financeira, ainda fundamentou seu entendimento nas garantias consumeristas de acesso à informação adequada, clara e precisa acerca dos produtos e serviços fornecidos no mercado (arts. $6^{\circ}$, inc. III, 20, 31, 35 e 54, $\S 5^{\circ}$, todos do CDC).

A temática do interesse processual em ações de exibição, conforme será visto, voltou a gerar discussões (principalmente no que diz respeito ao critério de adequação) com a entrada em vigor do Código de Processo Civil de 2015 (CPC) que, construído sobre um conjunto de princípios e valores distintos do $\mathrm{CPC} / 73$, alterou a maneira de enxergar o processo e reformou o regime de produção de provas.

\section{O CÓDIGO DE PROCESSO CIVIL DE 2015: PRINCÍPIOS NORTEADORES E DIREITO AUTÔNOMO À PROVA}

4.

O processo entendido a partir de uma concepção funcional tripartite se presta a (i) dirimir conflitos, (ii) dar azo à tutela jurisdicional e (iii) auxiliar na concretização de direitos $^{25}$. Projetado no intuito de gerar um processo justo, célere e menos complexo, atendendo às necessidades sociais ${ }^{26}$, o CPC/2015 buscou proporcionar coesão ao sistema processual, auxiliando o juiz a se concentrar no mérito da causa ${ }^{27}$, instituindo o chamado "princípio da primazia do julgamento de mérito" (art. 4, do CPC).

Não obstante, o CPC/2015 se sustenta nos princípios da cooperação (arts. $5^{\circ}$ e $6^{\circ}$ ), da celeridade (arts. $4^{\circ}$ e $8^{\circ}$ ) e da autocomposição (art. $2^{\circ}$ e $\left.3^{\circ}\right)^{28}$. Seguindo a tendência mundial de adotar "meios alternativos de solução de disputas, tornando a solução judicial uma

25 FARIA, Márcio Carvalho; GALVÃO FILHO, Maurício Vasconcelos; HARTMANN, Guilherme Kronemberg; GUEDES, Clarissa Diniz; ARAÚJO, José Aurélio de; SILVA, Franklyn Roger Alves. Anteprojeto do Grupo de Pesquisa "Observatório das Reformas Processuais" Faculdade de Direito da Universidade do Estado do Rio de Janeiro, Revista de Processo, vol. 241/2015, p. 111 - 201, Mar / 2015, p. 02 .

${ }^{26}$ Código de processo civil e normas correlatas. - 7. ed. - Brasília : Senado Federal, Coordenação de Edições Técnicas, 2015, p. 25.

${ }^{27}$ Ibidem, p. 26.

${ }^{28}$ WAMBIER, Luiz Rodrigues. Diretrizes fundamentais do novo CPC. In: WAMBIER, Luiz Rodrigues; WAMBIER, Teresa Arruda Alvim. Temas Essenciais do Novo CPC: Análise das principais alterações do sistema processual civil brasileiro de acordo com a lei $\mathbf{n}^{\mathbf{0}} \mathbf{1 3 . 2 5 6 / 2 0 1 6}$. São Paulo: Editora Revista dos Tribunais, 2016, p. 238. 
Revista Eletrônica de Direito Processual - REDP.

Rio de Janeiro. Ano 13. Volume 20. Número 3. Setembro a Dezembro de 2019

Periódico Quadrimestral da Pós-Graduação Stricto Sensu em Direito Processual da UERJ

Patrono: José Carlos Barbosa Moreira (in mem.). ISSN 1982-7636. pp. 145-186 www.redp.uerj.br

espécie de ultima ratio para a composição de litígios" ${ }^{29}$, as ferramentas autocompositivas negociação direita, conciliação, mediação e arbitragem - passaram a ser comtempladas como as primeiras opções de tratamento e solução dos $\operatorname{conflitos}^{30}$. Dito de outra forma, ao menos para certa gama ou categoria de conflitos, parece aceitável concluir que o meio alternativo deva ser a própria jurisdição (e não o contrário, como até então se propugnou).

Visar soluções céleres e eficientes implica incentivar a cooperação e a flexibilidade procedimental $^{31}$. Ainda que seja devido resguardar formalidades mínimas, a solução do conflito deve atentar, principalmente, ao contraditório e à participação ativa das partes, de modo que, se a aplicação da norma tal qual positivada não proporcionar a efetividade do direito material, deveráo julgador adaptar o procedimento para garantir constitucionalmente um processo justo ${ }^{32}$.

Vê-se que o processo civil se plasmou pelos ditames da Constituição Federal (CF), incorporando garantias fundamentais "como matriz axiológica de interpretação e aplicação das leis processuais, centradas na garantia à dignidade da pessoa (art. $8^{\circ}$ ) - direitos individuais e de cidadania (políticos) - e no princípio da primazia da resolução de mérito e da satisfação do direito material (art. $\left.4^{\circ}\right)^{\prime 33}$.

Um sistema processual comprometido com a solução eficiente de conflitos, entretanto, deve possuir um regime probatório funcional. A concepção clássica entende a prova como um meio "de aproximar o julgador da verdade possível a respeito dos fatos articulados e debatidos pelos sujeitos do processo para, a partir de seu delineamento, tornar-se viável a prestação de tutela jurisdicional" ${ }^{34}$. O CPC/2015, por sua vez, estendeu essa noção para além do caráter meramente instrumental, fazendo do direito material à

\footnotetext{
${ }^{29}$ ARENHART, Sérgio Cruz; MARINONI, Luiz Guilherme; MITIDIERO, Daniel. Novo curso de processo civil: tutela de direitos mediante procedimento comum. São Paulo: Editora Revista dos Tribunais, 2015, p. 173.

${ }^{30}$ CURY, Cesar Felipe. Produção antecipada de prova e disclosure no direito brasileiro. Revista FONAMEC - Rio de Janeiro, v.1, n. 1, p. 111 - 131, maio 2017, p. 119.

${ }^{31}$ FUGA, Augusto Sampaio. Provas no novo CPC: teoria geral das provas. Provas em espécie - inovações e implicações práticas. A teoria do ônus da dinâmico probatório. Novidades da fase instrutória. RVMD, Brasília, V. 9, nº 2, p. 330-362, Jul-Dez, 2015, p. 11.

${ }^{32}$ Ibidem, p. 12.

${ }^{33}$ CURY, Cesar Felipe. Produção antecipada de prova e disclosure no direito brasileiro. Revista FONAMEC - Rio de Janeiro, v.1, n. 1, p. 111 - 131, maio 2017, p. 120.

${ }^{34}$ LIPPMANN, Rafael Knorr. A "inédita" tutela do direito material (e autônomo) de acesso à prova. Disponível em: 〈http://www.emap.com.br/Nucleo\%20de\%20Pesquisas\%20Avancadas\%20da\%20EMAP/>. Acesso em: junho de 2018.
} 
Revista Eletrônica de Direito Processual - REDP.

Rio de Janeiro. Ano 13. Volume 20. Número 3. Setembro a Dezembro de 2019

Periódico Quadrimestral da Pós-Graduação Stricto Sensu em Direito Processual da UERJ

Patrono: José Carlos Barbosa Moreira (in mem.). ISSN 1982-7636. pp. 145-186

www.redp.uerj.br

prova “um direito 'próprio' e que, como tal, pode constituir o objeto de uma demanda, cujo pedido (único) consistirá na realização da prova, pura e simplesmente"35.

$\mathrm{O}$ direito à prova e sua ampla produção encontra fundamento constitucional no artigo $5^{\circ}$, inciso LV, da Constituição Federal, consectário das garantias fundamentais ao devido processo legal, ao contraditório e à ampla defesa ${ }^{36}$. Na mesma linha, ancora-se no artigo $8^{\circ}$, do Pacto de São José da Costa Rica (internalizado através do Dec. 678/1969) ${ }^{37}$, e no artigo 14, inciso I e alínea “e”, do Pacto Internacional dos Direitos Civis e Políticos (internalizado por meio do Dec. 592/1992) $)^{38}$.

Até mesmo em legislações infraconstitucionais anteriores ao CPC/2015, o direito à prova já reverberava, ainda que timidamente. O CPC/73 trazia uma semente do instituto, ao autorizar a produção de prova testemunhal nos artigos 861-866 (art. 381, §5º do CPC/2015), que disciplinavam o instituto da justificação, facultando a juntada de documentos, independentemente de haver risco ou da utilização da prova produzida em uma demanda futura ${ }^{39}$.

Alguns autores vislumbravam, para além do instituto da justificação, as vantagens de um procedimento autônomo de produção de provas desvinculado dos critérios da tutela cautelar e da exigência de posterior ajuizamento de ação de conhecimento. Preconizava-se que tal instrumento poderia ser utilizado pelas partes para avaliarem suas "chances de êxito

\footnotetext{
${ }^{35}$ Ibidem.

${ }^{36}$ ARENHART, Sérgio Cruz; MARINONI, Luiz Guilherme; MITIDIERO, Daniel. Novo curso de processo civil: tutela de direitos mediante procedimento comum. São Paulo: Editora Revista dos Tribunais, 2015, p. 252; CAMPOS, Felipe de Almeida; FREITAS, Sérgio Henriques Zandona. O instituto jurídico da prova no direito processual brasileiro. Argumenta Journal Law, n. 25 - jul/dez, 2016; DIDIER JR., Fredie. Ações autônomas de produção de provas: produção antecipada de prova e justificação. Revista de processo, vol. 218/2013, p. 13-45, Abr/2013; MANUCCI, Renato Pessoa. Panorama dos meios de prova no novo CPC. Disponível em: $\quad$ https://df8aa6jbtsnmo.cloudfront.net/download/Aula\%2007\%20\%20Direito\%20Processual\%20Civil\%20-\%20Leitura.pdf $>$. Acesso em: abril de 2018.

${ }^{37}$ Artigo $8^{\circ}$ - Garantias judiciais. 1. Toda pessoa terá o direito de ser ouvida, com as devidas garantias e dentro de um prazo razoável, por um juiz ou Tribunal competente, independente e imparcial, estabelecido anteriormente por lei, na apuração de qualquer acusação penal formulada contra ela, ou na determinação de seus direitos e obrigações de caráter civil, trabalhista, fiscal ou de qualquer outra natureza.

${ }^{38}$ Artigo 14.1. Todas as pessoas são iguais perante os tribunais e as cortes de justiça. Toda pessoa terá o direito de ser ouvida publicamente e com devidas garantias por um tribunal competente, independente e imparcial, estabelecido por lei, na apuração de qualquer acusação de caráter penal formulada contra ela ou na determinação de seus direitos e obrigações de caráter civil. [...] e) De interrogar ou fazer interrogar as testemunhas de acusação e de obter o comparecimento eo interrogatório das testemunhas de defesa nas mesmas condições de que dispõem as de acusação;

${ }^{39}$ ALVIM, Arruda. Manual de direito processual civil: teoria do processo e processo de conhecimento. São Paulo: Editora Revista dos Tribunais, 2017, p. 863.
} 
Revista Eletrônica de Direito Processual - REDP.

Rio de Janeiro. Ano 13. Volume 20. Número 3. Setembro a Dezembro de 2019

Periódico Quadrimestral da Pós-Graduação Stricto Sensu em Direito Processual da UERJ

Patrono: José Carlos Barbosa Moreira (in mem.). ISSN 1982-7636. pp. 145-186

www.redp.uerj.br

em eventual processo de certificação de direito material"40, proporcionando melhores condições à elaboração de estratégias processuais ou negociais e oportunizando uma "melhor apreciação das chances e dos riscos decorrentes do ajuizamento de uma ação, ou do oferecimento de peça de resistência"41.

No ano de 2014, o Marco Civil da Internet (Lei ${ }^{\circ}$ 12.965/2014) ampliou a figura do direito autônomo à prova, prevendo - com o intuito formar um conjunto probatório, em caráter incidental ou autônomo - a possibilidade de requerer ao juízo que determine ao responsável o fornecimento de registros de conexão ou de registros de acesso a aplicações na internet.

Com a evolução dos institutos processuais, a antiga controvérsia sobre o objeto de proteção da medida cautelar probatória (se protegia o direito de ação ou o direito material a ser pleiteado em ação futura) perdeu sua razão de ser, sendo hoje amplamente reconhecido que por meio de demandas probatórias autônomas se protege o direito à prova.

O juiz não é mais o único destinatário da prova. As partes têm o direito amplo a acessar elementos probatórios para que

[...] possam certificar-se sobre a ocorrência ou inocorrência de determinados fatos, obtendo assim uma noção mais adequada sobre a veracidade da narração fática e os direitos que efetivamente lhe são devidos, podendo [...] servir como estratégia processual para incentivar um prévio acordo entre as partes, antes do ingresso da ação ou logo no início do seu curso, ou mesmo para evitar o ajuizamento de demandas temerárias ${ }^{42}$.

$\mathrm{O}$ direito à prova se materializa em seu amplo acesso, englobando a faculdade de requerê-la em processo judicial, tê-la admitida, produzida e, posteriormente, valorada ${ }^{43}$. A parte tem o direito aproduzir provas, "antes e independentemente do processo, por uma

\footnotetext{
${ }^{40}$ DIDIER JR., Fredie. Ações autônomas de produção de provas: produção antecipada de prova e justificação. Revista de processo, vol. 218/2013, p. 13-45, Abr/2013, p. 05.

${ }^{41}$ MENEZES, Pedro Henrique da Silva; RANGEL, Marco Aurélio Scampini Siqueira. Análise comparativa entre o regime de produção antecipada de provas no projeto do novo CPC brasileiro e o CPC português de 2013. RIDB, Ano 3 (2014), no 5, p. 09.

${ }^{42}$ SOUSA, Ana Clara Ângelo Teixeira. A produção antecipada de provas no novo CPC como estratégia para uma rápida solução do litígio. Disponível em: $\langle$ http://www.direitoprocessual.org.br/aid=37.html?shop cat=23\&shop detail=426 $>$. Acesso em: abril de 2018.

${ }^{43}$ LAUX, Francisco de Mesquita. Relações entre a antecipação da prova sem o requisito da urgência e a construção de soluções autocompositivas. Revista de Processo, vol. 242/2015, p. 457 - 481,Abr / 2015, p. 02 .
} 
Revista Eletrônica de Direito Processual - REDP.

Rio de Janeiro. Ano 13. Volume 20. Número 3. Setembro a Dezembro de 2019

Periódico Quadrimestral da Pós-Graduação Stricto Sensu em Direito Processual da UERJ

Patrono: José Carlos Barbosa Moreira (in mem.). ISSN 1982-7636. pp. 145-186 www.redp.uerj.br

série de razões: avaliar suas chances efetivas numa futura e eventual disputa litigiosa, estimar os custos de tal disputa, verificar as possibilidades e termos de um possível acordo com o adversário" "44. Noutras palavras, "os interessados podem pleitear, junto ao Estado, uma pretensão de busca, obtenção e produção de providências de instrução, sem que, para tanto, haja estrita vinculação a um direito material" 45 .

Entretanto, ao direito à prova correspondem deveres anteriormente mencionados, correspondentes à lealdade, boa-fé processual e colaboração para com a efetivação da atividade jurisdicional e o deslinde do trâmite processual (art. 378 ${ }^{46}$, do CPC/2015). Aquele que descumpri-los estará sujeito a penalidades, nos termos dos artigos 80 e 81, do $\mathrm{CPC} / 2015$.

A despeito da possibilidade de produzir provas em ação de conhecimento, envolvendo pretensão material, o ordenamento jurídico contempla três modalidades de ação probatória autônoma: a produção antecipada de prova, a exibição de documento e a arguição de falsidade. As duas primeiras, situadas no Capítulo XII - Das Provas, serão objeto de análise nos itens seguintes.

\section{O INSTITUTO DA PRODUÇÃO ANTECIPADA DE PROVA (ARTS. 381 E 383, DO CPC/2015).}

A produção antecipada de prova ou, como parte da doutrina convencionou chamar, ação autônoma de produção de prova, “[...] tem natureza jurídica de ação, ou seja, decorre do direito constitucional subjetivo de demandar prestação jurisdicional (art. $5^{\circ}, \mathrm{XXXV}$, $\mathrm{CF}$ ) para um fim pontual e específico: obter acesso à prova, como direito material de cunho satisfativo" $"$.

Com a entrada em vigor do CPC/2015, os antigos institutos da produção antecipada de provas (art. 846-851, do CPC/73), do arrolamento de bens (arts. 855-860, do CPC/73) e da justificação (arts. 861-866, do CPC/73) perderam sua catalogação no rol dos

\footnotetext{
${ }^{44}$ TALAMINI, Eduardo. Produção antecipada de prova no código de processo civil de 2015. Revista de Processo, vol. 260/2016, p. 75 - 101, Out / 2016, p. 02.

${ }^{45}$ CARVAlHo FILHO, João Francisco Liberato de Mattos. Prova Antecipada no Código de Processo Civil Brasileiro. 245f. Salvador, 2017. Dissertação (Mestrado em Direito) - Programa de Pós-graduação da Universidade Federal da Bahia (UFBA), p. 66.

${ }^{46}$ Art. 378. Ninguém se exime do dever de colaborar com o Poder Judiciário para o descobrimento da verdade.

${ }^{47}$ LIPPMANN, Rafael Knorr. A "inédita" tutela do direito material (e autônomo) de acesso à prova. Disponível em: 〈http://www.emap.com.br/Nucleo\%20de\%20Pesquisas\%20Avancadas\%20da\%20EMAP/>. Acesso em: junho de 2018.
} 
Revista Eletrônica de Direito Processual - REDP.

Rio de Janeiro. Ano 13. Volume 20. Número 3. Setembro a Dezembro de 2019

Periódico Quadrimestral da Pós-Graduação Stricto Sensu em Direito Processual da UERJ

Patrono: José Carlos Barbosa Moreira (in mem.). ISSN 1982-7636. pp. 145-186

www.redp.uerj.br

procedimentos cautelares e foram unificados em um único procedimento de produção antecipada de prova, previsto nos artigos 381 a 383, do CPC. O arrolamento é especificado no artigo $381, \S 1^{\circ}$, enquanto a justificação se encontra no artigo $381, \S 5^{\circ}$, ambos do atual diploma processual civil.

O fato de a cautelar de exibição (arts. 844-845, do CPC/73) ter ou não sido englobada pelo referido procedimento enseja debate na doutrina, objeto principal do presente artigo, que será posteriormente averiguado. Vale pontuar, entretanto, que a fusão de algumas das cautelares nominadas do antigo código já era almejada pela doutrina processualista, principalmente no que tange à produção antecipada de prova e à justificação, "em razão da superposição que havia entre os procedimentos - a produção antecipada de prova $(\mathrm{CPC} / 73)$ servia à prova testemunhal, mas pressupunha urgência; a justificação apenas servia à prova testemunhal, e dispensava urgência"48.

O autor, na inicial da demanda em comento, deve explicitar a natureza da prova a ser produzida, as razões pelas quais pretende produzi-la antecipadamente e os fatos sobre os quais recairá (art. 382, do CPC) ${ }^{49}$. Costuma-se ressaltar a "natureza dúplice"50 da demanda, à medida que a prova produzida poderá ser utilizada tanto pelo autor, quanto pelo réu. Ademais, o interessado dispõe da possibilidade de requerer, no mesmo processo, a produção de outras provas relacionadas aos mesmos fatos, desde que não implique excessiva demora ${ }^{51}$ (art. 382, $\S 3^{\circ}$, do $\mathrm{CPC}^{52}$ ).

Conforme pontua Eduardo Talamini, a ação de produção antecipada de provas "é utilizável apenas quando não houver processo em curso, no qual se vá usar a prova. Se tal processo já estiver em curso, e houver a necessidade da antecipação de uma prova (i.e., sua produção antes da fase instrutória), aplica-se o art. 139, VI, do CPC/2015",53, que autoriza o juiz da demanda a "dilatar os prazos processuais e alterar a ordem de produção dos meios

\footnotetext{
${ }^{48}$ DIDIER JR., Fredie. Curso de direito processual civil: teoria da prova, direito probatório, decisão, precedente, coisa julgada e tutela provisória. Salvador: Ed. Jus Podivm, 2018, p. 164.

${ }^{49}$ Art. 382. Na petição, o requerente apresentará as razões que justificam a necessidade de antecipação da prova e mencionará com precisão os fatos sobre os quais a prova há de recair.

${ }^{50}$ WAMBIER, Luiz Rodrigues. Diretrizes fundamentais do novo CPC. In: WAMBIER, Luiz Rodrigues; WAMBIER, Teresa Arruda Alvim. Temas Essenciais do Novo CPC: Análise das principais alterações do sistema processual civil brasileiro de acordo com a lei $\mathbf{n}^{0} \mathbf{1 3 . 2 5 6 / 2 0 1 6}$. São Paulo: Editora Revista dos Tribunais, 2016, p. 239.

${ }^{51}$ TALAMINI, Eduardo. Produção antecipada de prova no código de processo civil de 2015. Revista de Processo, vol. 260/2016, p. 75 - 101, Out / 2016, p. 13.

${ }^{52} \mathrm{Art}$. 382. [...] $\$ 33^{\circ}$ Os interessados poderão requerer a produção de qualquer prova no mesmo procedimento, desde que relacionada ao mesmo fato, salvo se a sua produção conjunta acarretar excessiva demora.

${ }^{53}$ TALAMINI, Eduardo. Produção antecipada de prova no código de processo civil de 2015. Revista de Processo, vol. 260/2016, p. 75 - 101, Out / 2016, p. 03.
} 
Revista Eletrônica de Direito Processual - REDP.

Rio de Janeiro. Ano 13. Volume 20. Número 3. Setembro a Dezembro de 2019

Periódico Quadrimestral da Pós-Graduação Stricto Sensu em Direito Processual da UERJ

Patrono: José Carlos Barbosa Moreira (in mem.). ISSN 1982-7636. pp. 145-186

www.redp.uerj.br

de prova, adequando-os às necessidades do conflito de modo a conferir maior efetividade à tutela do direito".

Um debate relevante alude às etapas da produção probatória, que se dividem em: (i) proposição; (ii) admissão; (iii) produção; e (iv) valoração da prova. Parcela da doutrina ${ }^{54}$ considera que, no caso da produção antecipada, a prova é, efetivamente, produzida, atingindo-se a terceira fase retro citada e somente não passando pela etapa de valoração, que "será feita em outro momento; isso se houver necessidade, já que o requerente pode não ajuizar futura demanda"55. Outra parcela sustenta que há somente uma produção parcial, "já que a produção integral só se dará em outra ação, quando admitidas e valoradas as provas" $" 56$.

A dissonância entre as duas linhas de raciocínio se dá em razão de aquela levar mais a sério do que esta o caráter autônomo da demanda de produção antecipada de prova. A segunda perspectiva, afastando-se da melhor razão, aproxima-se do entendimento de que a ação probatória autônoma se presta à mera asseguração da prova, uma vez que a produção da prova somente ocorreria mediante requerimento e admissão em ação ulterior, em que fosse reclamado direito material ${ }^{57}$. Essas linhas de raciocínio recaem no equívoco de continuar a vincular a prova produzida antecipadamente ao ajuizamento de demanda posterior, enfraquecendo a autonomia das demandas probatórias e do direito processual à prova. Pode-se ponderar, no máximo, a partir de uma noção funcionalista da prova - que somente enxergue sua completude quando conectada a questões materiais e, assim, reclame a etapa da valoração -, que a prova antecipada seja incompleta ${ }^{58}$. Contudo, o fato de não ser objeto de valoração não significa "que a prova não foi produzida efetivamente,

\footnotetext{
${ }^{54}$ ALVIM, Arruda. Manual de direito processual civil: teoria do processo e processo de conhecimento. São Paulo: Editora Revista dos Tribunais, 2017, p. 862, 866.

${ }^{55}$ DIDIER JR., Fredie. Curso de direito processual civil: teoria da prova, direito probatório, decisão, precedente, coisa julgada e tutela provisória. Salvador: Ed. Jus Podivm, 2018, p. 159.

${ }^{56}$ MEDINA, José Miguel Garcia. Novo Código de Processo Civil comentado. São Paulo: Editora Revista dos Tribunais, 2017, p. 691.

${ }^{57}$ ARENHART, Sérgio Cruz; MARINONI, Luiz Guilherme; MITIDIERO, Daniel. Novo curso de processo civil: tutela de direitos mediante procedimento comum. São Paulo: Editora Revista dos Tribunais, 2015; ARENHART, Sérgio Cruz; MARINONI, Luiz Guilherme; MITIDIERO, Daniel. Código de Processo Civil comentado. São Paulo: Thomsom Reuters Brasil, 2018, p. 518; CURY, Cesar Felipe. Produção antecipada de prova e disclosure no direito brasileiro. Revista FONAMEC - Rio de Janeiro, v.1, n. 1, p. 111 - 131, maio 2017.

${ }^{58}$ TALAMINI, Eduardo. Produção antecipada de prova no código de processo civil de 2015. Revista de Processo, vol. 260/2016, p. 75 - 101, Out / 2016, p. 15.
} 
Revista Eletrônica de Direito Processual - REDP.

Rio de Janeiro. Ano 13. Volume 20. Número 3. Setembro a Dezembro de 2019

Periódico Quadrimestral da Pós-Graduação Stricto Sensu em Direito Processual da UERJ

Patrono: José Carlos Barbosa Moreira (in mem.). ISSN 1982-7636. pp. 145-186 www.redp.uerj.br

mas apenas que ainda não houve convencimento do julgado quanto à existência, admissibilidade ou veracidade dos fatos objeto da prova"59.

Em resumo, desenvolvendo-se por meio de "procedimento sumário (a ponto de excluir contestação e recursos) e cognição sumária horizontal (o juiz averigua superficialmente o pressuposto para antecipar a prova) e vertical (o juiz não se pronuncia sobre o mérito" ${ }^{60}$, o instituto da produção antecipada de prova enfatiza o direito autônomo à prova, visando "redução da litigiosidade, seja por incentivar as partes a transigirem, seja por desestimulá-las a promoverem demandas fadadas ao insucesso" ${ }^{61}$. Não havendo valoração da prova produzida, a sentença é "meramente homologatória e atesta que a prova foi produzida, tão somente" ${ }^{2}$.

A despeito da controvérsia, o fundamental é que, facilitando o acesso à prova, permite-se que os interessados avaliem adequadamente os riscos de uma eventual disputa judicial e as vantagens de solucionar a questão através da autocomposição ${ }^{63}$. Não se trata de uma medida cautelar, mas do exercício do direito à prova ${ }^{64}$ por meio de um instituto que

\footnotetext{
${ }^{59}$ CARVAlho FILHO, João Francisco Liberato de Mattos. Prova Antecipada no Código de Processo Civil Brasileiro.245f. Salvador, 2017. Dissertação (Mestrado em Direito) - Programa de Pós-graduação da Universidade Federal da Bahia (UFBA), p. 49.

${ }^{60}$ TALAMINI, Eduardo. Produção antecipada de prova no código de processo civil de 2015. Revista de Processo, vol. 260/2016, p. 75 - 101, Out / 2016, p. 02.

${ }^{61}$ WAMBIER, Teresa Arruda Alvim [et al.]. Primeiros comentários ao novo código de processo civil: artigo por artigo. São Paulo: Editora Revista dos Tribunais, 2016, p. 735.

${ }^{62}$ ALVIM, Arruda. Manual de direito processual civil: teoria do processo e processo de conhecimento. São Paulo: Editora Revista dos Tribunais, 2017, p. 864.

${ }^{63}$ LAUX, Francisco de Mesquita. Relações entre a antecipação da prova sem o requisito da urgência e a construção de soluções autocompositivas. Revista de Processo, vol. 242/2015, p. 457 - 481,Abr / 2015, p. 02; MEDINA, José Miguel Garcia. Novo Código de Processo Civil comentado. São Paulo: Editora Revista dos Tribunais, 2017, p. 689; SOUSA, Ana Clara Ângelo Teixeira. A produção antecipada de provas no novo CPC como estratégia para uma rápida solução do litígio. Disponível em: 〈http://www.direitoprocessual.org.br/aid=37.html?shop_cat=23\&shop_detail=426>. Acesso em: abril de 2018.

${ }^{64}$ SOUSA, Ana Clara Ângelo Teixeira. A produção antecipada de provas no novo CPC como estratégia para uma rápida solução do litígio. <http://www.direitoprocessual.org.br/aid=37.html?shop_cat=23\&shop_detail=426>. Acesso em: abril de 2018.
} 
Revista Eletrônica de Direito Processual - REDP.

Rio de Janeiro. Ano 13. Volume 20. Número 3. Setembro a Dezembro de 2019

Periódico Quadrimestral da Pós-Graduação Stricto Sensu em Direito Processual da UERJ

Patrono: José Carlos Barbosa Moreira (in mem.). ISSN 1982-7636. pp. 145-186 www.redp.uerj.br

tem por propósito primordial a redução da litigiosidade ${ }^{65}$ e a promoção da "cooperação das partes com a administração da justiça" ${ }^{\circ 6}$.

Nos termos do artigo 381, do CPC, a produção antecipada de prova não mais se restringe à hipótese cautelar (art. 381, inc. I), podendo ser realizada, também, quando for útil à resolução extrajudicial do conflito entre as partes (art. 381, inc. III), evitando o ajuizamento de possível demanda litigiosa (art. 381, inc. III). As grandes mudanças proporcionadas pelo $\mathrm{CPC} / 2015$ foram tornar aplicável a produção antecipadade provas mesmo na ausência de periculum in mora ${ }^{67}$ e desvinculá-la do ajuizamento de ação de conhecimento posterior, "deixando assim mais evidente o se caráter autônomo"68.

Não se pode tornar defeso à parte, quando da hipótese cautelar calcada na urgência (periculum in mora), optar entre a adoção do procedimento prevista no artigo 305 a 310, do CPC - arcando com o ônus de apresentar, em até trinta dias após a efetivação da tutela cautelar, o pedido principal -, ou do instrumento contido nos artigos 381 a 383, do CPC sem a necessidade de propor demanda ulterior, conforme o enunciado da I Jornada de Direito Processual Civil, ocorrida em 2017: “A eficácia da produção antecipada de provas não está condicionada a prazo para a propositura de outra ação"69.

Trata-se de uma faculdade da parte escolher o procedimento que, não sendo integralmente inadequado ao propósito da demanda, mais lhe atenda os interesses. Poderse-á, dessa forma, optar entre uma ação de conhecimento em que a produção antecipada de prova seja feita incidentalmente e antes da apresentação do pedido principal, ou uma ação probatória autônoma, cujo núcleo será o exercício do direito à prova, pura e simplesmente.

Ainda, havendo extrema urgência, em casos nos quais não se possa esperar pela citação do requerido, ou quando houver receio de que este, uma vez citado, frustre a

\footnotetext{
${ }^{65}$ FUGA, Augusto Sampaio. Provas no novo CPC: teoria geral das provas. Provas em espécie - inovações e implicações práticas. A teoria do ônus da dinâmico probatório. Novidades da fase instrutória. RVMD, Brasília, V. 9, n 2, p. 330-362, Jul-Dez, 2015, p. 20; MENEZES, Pedro Henrique da Silva; RANGEL, Marco Aurélio Scampini Siqueira. Análise comparativa entre o regime de produção antecipada de provas no projeto do novo CPC brasileiro e o CPC português de 2013. RIDB, Ano 3 (2014), no 5 , p. 11.

${ }^{66}$ ARAÚJO, José Aurélio de. Capítulo IV - Procedimento probatório extrajudicial. In: Revista Eletrônica de Direito Processual - REDP. Volume XIII.Periódico da Pós-Graduação Stricto Sensu em Direito Processual da UERJ, p. 395.

${ }^{67}$ NEVES, Daniel Amorim Assumpção. Manual de direito processual civil. Salvador: JusPodivm, 2018, p. 755.

${ }^{68}$ FUGA, Augusto Sampaio. Provas no novo CPC: teoria geral das provas. Provas em espécie - inovações e implicações práticas. A teoria do ônus da dinâmico probatório. Novidades da fase instrutória. RVMD, Brasília, V. 9, nº 2, p. 330-362, Jul-Dez, 2015, p. 18.

${ }^{69}$ I Jornada de Direito Processual Civil : enunciados aprovados, Brasília/DF, 24 e 25 de agosto de 2017. Brasília : Conselho da Justiça Federal, Centro de Estudos Judiciários, 2017.
} 
Revista Eletrônica de Direito Processual - REDP.

Rio de Janeiro. Ano 13. Volume 20. Número 3. Setembro a Dezembro de 2019

Periódico Quadrimestral da Pós-Graduação Stricto Sensu em Direito Processual da UERJ

Patrono: José Carlos Barbosa Moreira (in mem.). ISSN 1982-7636. pp. 145-186

www.redp.uerj.br

produção da prova, é possível elaborar pedido de urgência, caracterizado como "uma tutela provisória satisfativa do direito à produção da prova antecipada, por mais estranho que pareça [...] Seria uma espécie de tutela provisória fundada exclusivamente na urgência"70.

Definir o caráter voluntário ou contencioso da medida em exame também não é tarefa simples. Enquanto para alguns autores, a produção antecipada de prova configura um procedimento de jurisdição voluntária, para outros, poderia ser tanto de jurisdição voluntária, quanto contenciosa, a depender da existência de conflito a ser dirimido por meio da prova que se pretende produzir. Didier Jr. se filia à primeira posição, atribuindo ao instituto o caráter de "típico procedimento de jurisdição voluntária [...] pelo fato de que não há necessidade de afirmação do conflito em torno da produção da prova"71.

Entretanto, a razão parece estar com os que alegam não ser possível "tachar em abstrato se os processos probatórios em geral teriam natureza de jurisdição voluntária ou contenciosa, nem tampouco vincular tal enquadramento à eventual ação futura"72. De acordo com os princípios da eventualidade e causalidade, deverá ser condenado ao pagamento de verbas sucumbenciais aquele que der causa à demanda. Ou seja, havendo resistência por parte do demandado à produção da prova, considerar-se-á contenciosa a demanda, diferentemente de quando a produção se der sem óbice do réu, ou mesmo sem que haja parte requerida.

Nessa linha, o procedimento será considerado voluntário (não contencioso) quando tiver por único e exclusivo propósito a documentação do interessado, sem que haja demonstração de interesse na utilização da prova produzida em demanda judicial futura (art. 382, §1 $1^{\circ}$, do CPC). Neste caso, poder-se-ia argumentar com a dispensa de citação de outros sujeitos - ocasionando uma das únicas hipóteses de demanda judicial sem réu $^{73}$ no ordenamento jurídico pátrio - em que não são fixadas verbas sucumbenciais. Note-se que a interpretação deve iniciar, a partir da narrativa exposta pelo autor em inicial, com a verificação da existência de sujeito interessado a ocupar o polo passivo da demanda, para

\footnotetext{
${ }^{70}$ DIDIER JR., Fredie. Curso de direito processual civil: teoria da prova, direito probatório, decisão, precedente, coisa julgada e tutela provisória. Salvador: Ed. Jus Podivm, 2018, p. 166.

${ }^{71}$ Ibidem, p. $159-161$.

${ }^{72}$ CARVAlHo FILHO, João Francisco Liberato de Mattos. Prova Antecipada no Código de Processo Civil Brasileiro.245f. Salvador, 2017. Dissertação (Mestrado em Direito) - Programa de Pós-graduação da Universidade Federal da Bahia (UFBA), p. 94.

${ }^{73}$ ARENHART, Sérgio Cruz; MARINONI, Luiz Guilherme; MITIDIERO, Daniel. Código de Processo Civil comentado. São Paulo: Thomsom Reuters Brasil, 2018, p. 518-519; DIDIER JR., Fredie. Curso de direito processual civil: teoria da prova, direito probatório, decisão, precedente, coisa julgada e tutela provisória. Salvador: Ed. Jus Podivm, 2018, p. 167.
} 
Revista Eletrônica de Direito Processual - REDP.

Rio de Janeiro. Ano 13. Volume 20. Número 3. Setembro a Dezembro de 2019

Periódico Quadrimestral da Pós-Graduação Stricto Sensu em Direito Processual da UERJ

Patrono: José Carlos Barbosa Moreira (in mem.). ISSN 1982-7636. pp. 145-186 www.redp.uerj.br

que então, na ausência de qualquer interessado, seja reconhecida a voluntariedade do procedimento. A natureza voluntária da demanda somente vem à tona, portanto, após concluir-se pela dispensa da citação de interessados.

Havendo parte passiva contra a qual se pretenda utilizar a prova, mas que não apresente, administrativa ou judicialmente, resistência a sua produção, entender-se-á também, conforme o princípio da eventualidade, pela natureza voluntária da demanda. Contudo, caso seja ajuizada, posteriormente, ação de conhecimento correlata à prova produzida, na qual o mesmo demandado seja sucumbente, poderá este ser condenado ao ressarcimento das custas com as quais o autor teve de arcar ao deduzir o pleito de produção antecipada de prova.

Por fim, verificado conflito ou resistência em torno da produção da prova, haverá contenciosidade, dando azoa um novo debate, sobre o poder do juiz de, ex officio, citar interessados na ação (art. 382, $\S 1^{\circ}$, do CPC).

Parte da doutrina ${ }^{74}$ sustenta que haveria afronta do princípio dispositivo, pois o magistrado estaria incluindo réus no processo a despeito da vontade do autor. A fim de preservar a inércia do juiz, sustenta-se que a participação de interessado não indicado como réu pelo autor deveria se dar somente por meio de intimação, não citação. Ainda, poderia o juiz intimar "o autor para emendar a petição inicial e incluir o terceiro como réu sob pena de indeferimento da petição inicial e extinção do processo sob o fundamento de que sem a presença daquele sujeito a prova a ser produzida não terá eficácia vinculante ou a terá de forma muito restrita" ${ }^{75}$. Outra parcela ${ }^{76}$, cujo entendimento parece mais adequado, afirma se tratar de uma hipótese típica de intervenção iussuiudicis, ou seja, uma intervenção de terceiro por força de determinação judicial, rememorando ao artigo $91^{77}$, do CPC/1939. Poder-se-ia trazer ao processo, por exemplo, “o futuro denunciado a lide, com o propósito de inclui-lo no âmbito de eficácia da prova que se pretende produzir"78.

\footnotetext{
${ }^{74}$ NEVES, Daniel Amorim Assumpção. Manual de direito processual civil. Salvador: JusPodivm, 2018, p. 759.

${ }^{75}$ Ibidem, p. 759.

${ }^{76}$ DIDIER JR., Fredie. Curso de direito processual civil: teoria da prova, direito probatório, decisão, precedente, coisa julgada e tutela provisória. Salvador: Ed. Jus Podivm, 2018, p. 167.

${ }^{77}$ Art. 91 . O juiz, quando necessário, ordenará a citação de terceiros, para integrarem a contestação. Se a parte interessada não promover a citação no prazo marcado, o juiz absolverá o réu da instância.

${ }^{78}$ DIDIER JR., Fredie. Curso de direito processual civil: teoria da prova, direito probatório, decisão, precedente, coisa julgada e tutela provisória. Salvador: Ed. Jus Podivm, 2018, p. 171.
} 
Revista Eletrônica de Direito Processual - REDP.

Rio de Janeiro. Ano 13. Volume 20. Número 3. Setembro a Dezembro de 2019

Periódico Quadrimestral da Pós-Graduação Stricto Sensu em Direito Processual da UERJ

Patrono: José Carlos Barbosa Moreira (in mem.). ISSN 1982-7636. pp. 145-186

www.redp.uerj.br

Vale frisar que a possibilidade de defesa do demandado é circunscrita pelo artigo

$382, \S 4^{\circ}$, do CPC, que prevê não ser admissível "defesa ou recurso, salvo contra decisão que indeferir totalmente a produção da prova pleiteada pelo requerente originário". Alguns teóricos ${ }^{79}$ afirmam que, sob pena de afronta os princípios da isonomia processual, do contraditório e da ampla defesa ${ }^{80}$ e do duplo grau de jurisdição, a interpretação do citado artigo deve ser realizada mitigada e sistematicamente, o que gera discussões sobre os limites admitidos às defesas em contestação e mediante recurso neste tipo de demanda.

No que tange à contestação, parcela da doutrina entende que o réu pode trazer à tona matérias de ordem pública e cunho processual/formal (ilegitimidade das partes, interesse de agir, inadequação do meio de prova, etc.), sendo-lhe defeso discutir questões de mérito, envolvendo direito material, não apreciáveis neste tipo de demanda ${ }^{81}$. Por seu turno, autores para os quais o intuito do procedimento se limita à mera asseguração da prova, aduzem serem somente impugnáveis as decisões de indeferimento das provas ${ }^{82}$. A linha aqui adotada preconiza que a limitação das possibilidades de defesa deve ser compreendida como: “(a) ausência de uma via específica para formulação de contestação e (b) não cabimento de discussão sobre o mérito da pretensão (ou defesa) para a qual a prova pode servir no futuro" $" 83$.

No mesmo sentido, o Enunciado 32, da I Jornada de direito processual civil do Centro de Estudos Judiciários (CJF), do Conselho da Justiça Federal: “a vedação à

\footnotetext{
${ }^{79}$ DIDIER JR., Fredie. Curso de direito processual civil: teoria da prova, direito probatório, decisão, precedente, coisa julgada e tutela provisória. Salvador: Ed. Jus Podivm, 2018, p. 169; DINAMARCO, Cândido Rangel. Instituições de direito processual civil: volume III. São Paulo: Malheiros, 2017, p. 118119; WAMBIER, Teresa Arruda Alvim [et al.]. Primeiros comentários ao novo código de processo civil: artigo por artigo. São Paulo: Editora Revista dos Tribunais, 2016, p. 737.

${ }^{80}$ Art. $5^{\circ}$, CF. [...] LV - aos litigantes, em processo judicial ou administrativo, e aos acusados em geral são assegurados o contraditório e ampla defesa, com os meios e recursos a ela inerentes;

${ }^{81}$ DIDIER JR., Fredie.Ações autônomas de produção de provas: produção antecipada de prova e justificação. Revista de processo, vol. 218/2013, p. 13-45, Abr/2013;FUGA, Augusto Sampaio. Provas no novo CPC: teoria geral das provas. Provas em espécie - inovações e implicações práticas. A teoria do ônus da dinâmico probatório. Novidades da fase instrutória. RVMD, Brasília, V. 9, no 2, p. 330-362, Jul-Dez, 2015; WAMBIER, Luiz Rodrigues. Diretrizes fundamentais do novo CPC. In: WAMBIER, Luiz Rodrigues; WAMBIER, Teresa Arruda Alvim. Temas Essenciais do Novo CPC: Análise das principais alterações do sistema processual civil brasileiro de acordo com a lei $\mathbf{n}^{\mathbf{0}} \mathbf{1 3 . 2 5 6 / 2 0 1 6}$. São Paulo: Editora Revista dos Tribunais, 2016.

${ }^{82}$ ARENHART, Sérgio Cruz; MARINONI, Luiz Guilherme; MITIDIERO, Daniel. Novo curso de processo civil: tutela de direitos mediante procedimento comum. São Paulo: Editora Revista dos Tribunais, 2015.

${ }^{83}$ TALAMINI, Eduardo. Produção antecipada de prova no código de processo civil de 2015. Revista de Processo, vol. 260/2016, p. 75 - 101, Out / 2016, p. 12.
} 
Revista Eletrônica de Direito Processual - REDP.

Rio de Janeiro. Ano 13. Volume 20. Número 3. Setembro a Dezembro de 2019

Periódico Quadrimestral da Pós-Graduação Stricto Sensu em Direito Processual da UERJ

Patrono: José Carlos Barbosa Moreira (in mem.). ISSN 1982-7636. pp. 145-186

www.redp.uerj.br

apresentação de defesa prevista no art. $382, \S 4^{\circ}$, do CPC, não impede a alegação pelo réu de matérias defensivas conhecíveis de ofício" ${ }^{\text {. }}$.

Quanto à recorribilidade e ao duplo grau de jurisdição, a discussão acadêmica embrionária era calcada em hipóteses abstratas, envolvendo a possibilidade (ou não) de interposição de agravo de instrumento ${ }^{85}$ - quando a decisão recorrida se amoldasse ao rol do artigo 1.015, do CPC - ou ainda impugnação pela via do mandado de segurança empregado como sucedâneo recursal ${ }^{86}$. É certo que a questão perpassa a famigerada taxatividade (ou não) do rol previsto no art. 1.015 do CPC, questão ainda não pacificada no âmbito do Superior Tribunal de Justiça. Contudo, a prática processual trouxe à tona uma nova discussão, envolvendo advogados que interpõem recursos de apelação questionando o arbitramento de honorários sucumbenciais em demanda que alegam ser de jurisdição voluntária, o que impediria a fixação das referidas verbas. O Tribunal de Justiça do Estado do Paraná (TJPR) vem conhecendo de tais recursos, julgando a questão de mérito de acordo com o caso concreto ${ }^{87}$.

Por fim, vale examinar o paralelo que a doutrina costuma tecer entre o instituto processual hora em comento e as figuras do discovery e disclosure ${ }^{88}$, provenientes, respectivamente, do direito norte-americano e britânico.

Originada em 1938, no ordenamento jurídico norte-americano, a discovery tem por intuito "promover o intercâmbio de informações entre os litigantes, guardado o dever de colaboração" ${ }^{89}$, e estimular a autocomposição.

\footnotetext{
${ }^{84}$ I Jornada de Direito Processual Civil : enunciados aprovados, Brasília/DF, 24 e 25 de agosto de 2017. Brasília : Conselho da Justiça Federal, Centro de Estudos Judiciários, 2017.

${ }^{85}$ ARENHART, Sérgio Cruz; MARINONI, Luiz Guilherme; MITIDIERO, Daniel. Novo curso de processo civil: tutela de direitos mediante procedimento comum. São Paulo: Editora Revista dos Tribunais, 2015, p. 311-312.

${ }^{86}$ WAMBIER, Luiz Rodrigues. Diretrizes fundamentais do novo CPC. In: WAMBIER, Luiz Rodrigues; WAMBIER, Teresa Arruda Alvim. Temas Essenciais do Novo CPC: Análise das principais alterações do sistema processual civil brasileiro de acordo com a lei $\mathbf{n}^{\mathbf{0}}$ 13.256/2016. São Paulo: Editora Revista dos Tribunais, 2016, p. 240; NEVES, Daniel Amorim Assumpção. Novo Código de Processo Civil Comentado. Salvador: Ed. JusPodivm, 2018, p. 720.

${ }^{87} \mathrm{~A}$ título de exemplo: $\mathrm{AC} \mathrm{n}^{\circ}$ 0001401-30.2018.8.16.0148; $\mathrm{AC} \mathrm{n}^{\circ}$ 0008909-61.2017.8.16.0148; $\mathrm{AC} \mathrm{n}^{\mathrm{o}}$ 0069901-02.2017.8.16.0014; $\mathrm{AC} \mathrm{n}^{\circ}$ 0003357-19.2016.8.16.0159.

${ }^{88} \mathrm{O}$ procedimento é regulamentado na "Part 31 - DisclosureandInspectionofDocuments", disponível em: $\langle$ http://www.wipo.int/edocs/lexdocs/laws/en/gb/gb317en.pdf >

$\langle$ https://www.federalrulesofcivilprocedure.org/frcp/title-v-disclosures-and-discovery/>. Acesso em: julho de 2018.

${ }^{89}$ GUIMARÃES, Filipe. Medidas probatórias autônomas: panorama atual, experiência estrangeira e as novas possibilidades no direito brasileiro. Revista de Processo, vol. 178/2009, p. 123 - 152, Dez / 2009, p. 07.
} 
Revista Eletrônica de Direito Processual - REDP.

Rio de Janeiro. Ano 13. Volume 20. Número 3. Setembro a Dezembro de 2019

Periódico Quadrimestral da Pós-Graduação Stricto Sensu em Direito Processual da UERJ

Patrono: José Carlos Barbosa Moreira (in mem.). ISSN 1982-7636. pp. 145-186

www.redp.uerj.br

O sistema americano costuma separar o processo judicial em duas fases. "A fase preliminar, conhecida como pretrial ou pretrial discoveryserve para eventual apuração e delimitação de fatos e questões de direito que poderão ser objeto de apreciação quando do julgamento da causa, a trial ${ }^{\prime \prime 90}$.

À diferença da produção antecipada de prova, regida pela facultatividade e voluntariedade, a discovery configura fase pré-processual obrigatória, devendo as partes cientificarem-se das provas antes da ação ser ajuizada ${ }^{91}$ e podendo, até a ordem de prejulgamento (pretrialorder), alterar o pedido e seus fundamentos, relativizando-se a estabilização processual em prol da melhor solução do conflito. Isto ocorre, pois somente se atinge a fase de julgamento (trial),caso no pretrial, "a colheita das provas tenha evidenciado às partes a viabilidade (ou a provável viabilidade) do direito que será requerido" ${ }^{22}$.

A chamada disclosure, introduzida no ordenamento jurídico britânico, em 1998, pela Civil Procedure Rules (CPR), preconiza a apresentação de documentos pelas partes, permitindo ao potencial adversário examiná-los e obter cópias. Pode se dar antes do ajuizamento de demanda material - em etapa intitulada pre-action -, ou já com a demanda material proposta, mas antes de seu julgamento - em fase denominada pre-trial. A principal função é permitir às partes que "revelem documentos e informações, pautados nas regras dos chamados pre-action protocols, que são treze situações onde resta demonstrado de que modo devem as partes trocar os dados" ${ }^{\prime 93}$.

Normalmente, o instituto é aplicado tendo em vista a análise das condições (propícias ou não) ao ajuizamento futuro de uma ação judicial. Às partes é exigido, então, que tragam à tona não uma prova específica, mas tudo que guarde relação com o objeto da futura demanda. Caso não cumpram com seus encargos, "serão aplicadas as sanções relacionadas

\footnotetext{
${ }^{90}$ CARVAlho Filho, João Francisco Liberato de Mattos. Prova Antecipada no Código de Processo Civil Brasileiro.245f. Salvador, 2017. Dissertação (Mestrado em Direito) - Programa de Pós-graduação da Universidade Federal da Bahia (UFBA), p. 76.

${ }^{91}$ DOTTI, Rogéria; PINHEIRO, Paulo Eduardo d'Arce; MARTINS, Sandro Gilbert; KOZIKOSKI, Sandro Marcelo. Curso de processo civil completo. São Paulo: Editora Revista dos Tribunais, 2017, p. 713.

${ }^{92}$ CARVAlHO FILHO, João Francisco Liberato de Mattos. Prova Antecipada no Código de Processo Civil Brasileiro.245f. Salvador, 2017. Dissertação (Mestrado em Direito) - Programa de Pós-graduação da Universidade Federal da Bahia (UFBA), p. 77.

${ }^{93}$ Ibidem, p. 75.
} 
Rio de Janeiro. Ano 13. Volume 20. Número 3. Setembro a Dezembro de 2019

Periódico Quadrimestral da Pós-Graduação Stricto Sensu em Direito Processual da UERJ

Patrono: José Carlos Barbosa Moreira (in mem.). ISSN 1982-7636. pp. 145-186 www.redp.uerj.br

ao Contempt of Court, sem falar nos prejuízos subjetivos decorrentes de um sistema que é todo conformado com base na cooperação e boa-fé" 94 .

O juiz, ainda, pode limitar a documentação a ser fornecida ou determinar a prestação de informações adicionais, tendo em vista que a disclosure inclui "obrigatoriamente, a apresentação de informações relevantes e potencialmente fortalecedoras não somente dos argumentos apresentados pela parte que as revela, mas também dos dados que possam enfraquecer tais alegações, ou mesmo fortalecer aquelas apresentadas pela parte contrária"95.

Ambos os institutos, apesar de possuírem inúmeras diferenças em relação à produção antecipada de prova, permitem aos interessados, assim como esta, "ter acesso a maior volume de dados de controvérsia, e assim à formação de juízo sobre os fatos e mais adequada avaliação da pretensão" ${ }^{\prime 96}$.

\section{O INSTITUTO DA EXIBIÇÃO DE DOCUMENTO OU COISA (ARTS. 396 a 404, do CPC/2015)}

Diferentemente do que se fez com a ação de produção antecipada de provas (arts. 381 a 383, do CPC), a abordagem do instituto da exibição de documentos ou coisa (arts. 396 a 404, do CPC) não terá início com a análise de sua natureza jurídica, tendo em vista ser este o ponto fulcral do debate proposto nessa pesquisa, o qual será retomado adiante.

Assim, considerando a existência de pontos controvertidos sobre a atual funcionalidade do instituto, buscar-se-á abordar no presente item os pontos pacíficos na doutrina e as discussões que não envolvam a relação entre a exibição e a produção antecipada de provas, para depois, no item seguinte, tratar das questões desarmônicas envolvidas em disputas teóricas.

\footnotetext{
${ }^{94}$ Ibidem, p. 75-76.

${ }^{95}$ LAUX, Francisco de Mesquita. Relações entre a antecipação da prova sem o requisito da urgência e a construção de soluções autocompositivas. Revista de Processo, vol. 242/2015, p. 457 - 481, Abr / 2015, p. 05 .

${ }^{96}$ CURY, Cesar Felipe. Produção antecipada de prova e disclosure no direito brasileiro. Revista FONAMEC

- Rio de Janeiro, v.1, n. 1, p. 111 - 131, maio 2017, p. 124.
} 
Revista Eletrônica de Direito Processual - REDP.

Rio de Janeiro. Ano 13. Volume 20. Número 3. Setembro a Dezembro de 2019

Periódico Quadrimestral da Pós-Graduação Stricto Sensu em Direito Processual da UERJ

Patrono: José Carlos Barbosa Moreira (in mem.). ISSN 1982-7636. pp. 145-186 www.redp.uerj.br

O procedimento em questão está assentado em dois fundamentos diversos, um de índole material e outro de caráter processual. O primeiro remete ao direito de acesso ao documento ou coisa, ao passo em que o segundo alude ao direito de produzir prova ${ }^{97}$.

A possibilidade ou não de interposição de uma ação autônoma de exibição, com fulcro nos arts. 396-404, do CPC, também será analisada no item subsequente. Contudo, é convergente o entendimento de que o instituto pode (e a doutrina majoritária apregoa ser esta sua única possível aplicação) ser utilizado na pendência de uma ação principal, distintamente da produção antecipada de provas, não ajuizável quando houver ação de conhecimento em curso.

Assim como ocorria durante a vigência do $\mathrm{CPC} / 73$, no curso da demanda, o magistrado poderá, ex officio, determinar a exibição de documento, atendendo critérios de necessidade e utilidade, ancorado nos artigos $370^{98}$ e $396^{99}$, do CPC.

A exibição também pode ser requerida pela parte que, ao apresentar pleito, deverá individuar o documento ou coisa objeto do pedido, além de demonstrar a finalidade, o interesse e a pertinência da exibição. Conforme entendimento firmado pela jurisprudência, ainda na vigência do código revogado, a individuação deverá ser suficiente para não deixar dúvida a respeito do que se pretende ver exibido, não sendo exigida uma individuação perfeita e minuciosa:

Ação de exibição de documentos. Art. 356, I, do Código de Processo Civil. 1. Na ação de exibição de documentos é necessário que a parte autora faça a individuação do documento, não sendo suficiente referência genérica que torne inviável a apresentação pela parte ré. Ainda que não seja completa a individuação, deve ser bastante para a identificação dos documentos a serem apresentados. 2. Recurso especial conhecido e provido. (REsp 862.448/AL, Rel. Ministro CARLOS ALBERTO MENEZES DIREITO, TERCEIRA TURMA, julgado em 15/05/2007, DJ 25/06/2007, p. 236)

Havendo processo de conhecimento em curso, a elaboração do pedido de exibição assumirá feição distinta conforme o destinatário da ordem e possuidor do documento ou

\footnotetext{
${ }^{97}$ CARVAlho FILHO, João Francisco Liberato de Mattos. Prova Antecipada no Código de Processo Civil Brasileiro.245f. Salvador, 2017. Dissertação (Mestrado em Direito) - Programa de Pós-graduação da Universidade Federal da Bahia (UFBA).

${ }^{98}$ Art. 370. Caberá ao juiz, de ofício ou a requerimento da parte, determinar as provas necessárias ao julgamento do mérito.

${ }^{99}$ Art. 396. O juiz pode ordenar que a parte exiba documento ou coisa que se encontre em seu poder.
} 
Revista Eletrônica de Direito Processual - REDP.

Rio de Janeiro. Ano 13. Volume 20. Número 3. Setembro a Dezembro de 2019

Periódico Quadrimestral da Pós-Graduação Stricto Sensu em Direito Processual da UERJ

Patrono: José Carlos Barbosa Moreira (in mem.). ISSN 1982-7636. pp. 145-186

www.redp.uerj.br

coisa, com distinção das hipóteses envolvendo a contraparte da demanda ou um terceiro estranho à mesma.

Contra a parte adversária, tem-se um incidente processual $^{100}$, que tramitará de maneira correlata aos autos da ação principal e será resolvido por decisão interlocutória, sujeita à impugnação por meio do recurso de agravo ${ }^{101}$. O requerido terá o prazo de cinco dias para responder ao pedido (art. 398, do CPC). Caso permaneça inerte, não cumprindo com a ordem e nem a impugnando, ou caso a recusa à exibição seja entendida como ilegítima (art. 399, do CPC) opera-se efeito semelhante ao da revelia, sobrevindo presunção relativa de veracidade quanto aos fatos relativos à prova não produzida (art. 400, do $\mathrm{CPC} / 2015)^{102}$.

A inovação trazida pelo parágrafo único do artigo 400, que confere ao juiz a faculdade de, em caso de necessidade, "adotar medidas indutivas, coercitivas, mandamentais ou sub-rogatórias para que o documento seja exibido", gerou debates na doutrina, uma vez que a Súmula $\mathrm{n}^{\mathbf{0}} 372$, do STJ, editada em março de 2009, estabelecia que, na ação de exibição de documentos, não era cabível a aplicação de multa cominatória.

Conforme o Enunciado $\mathrm{n}^{\circ}$ 54, do FPPC/2017, prevalece o entendimento de estar superada a ratio decidendi subjacente à súmula da corte superior ${ }^{103}$, admitindo-se a aplicação de multa em procedimentos de exibição, ressalvando-se as hipóteses em que for impossível o cumprimento da determinação (Enunciado nº 53, do FPPC/2017).

Vale ressaltar, entretanto, que a questão da necessidade aparece como uma premissa à aplicação das medidas coercitivas previstas no artigo 400, parágrafo único, do CPC. Nesse sentido, há quem interprete, não sem razão, que o magistrado somente pode aplicar

\footnotetext{
${ }^{100}$ DINAMARCO, Cândido Rangel. Instituições de direito processual civil: volume III. São Paulo: Malheiros, 2017, p. 667.

${ }^{101}$ ALVIM, Arruda. Manual de direito processual civil: teoria do processo e processo de conhecimento. São Paulo: Editora Revista dos Tribunais, 2017, p. 917.

${ }^{102}$ FUGA, Augusto Sampaio. Provas no novo CPC: teoria geral das provas. Provas em espécie - inovações e implicações práticas. A teoria do ônus da dinâmico probatório. Novidades da fase instrutória. $\boldsymbol{R V} \boldsymbol{M D}$, Brasília, V. 9, nº 2, p. 330-362, Jul-Dez, 2015, p. 22; LOURENÇO, Haroldo. O direito probatório no novo CPC. Disponível em: 〈http://haroldolourenco.com.br/artigos/odireitoprobatorio.pdf $>$. Acesso em: junho de 2018..

${ }^{103}$ ARENHART, Sérgio Cruz; MARINONI, Luiz Guilherme; MITIDIERO, Daniel. Novo Código de Processo Civil comentado. São Paulo: Editora Revista dos Tribunais, 2017, p. 516; NEVES, Daniel Amorim Assumpção. Manual de direito processual civil. Salvador: JusPodivm, 2018, p. 780; PINHO, Humberto Dalla Bernardina de. Direito processual civil contemporâneo: processo de conhecimento, cautelar, execução e procedimentos especiais. São Paulo: Saraiva Educação, 2018, p. 227.
} 
Rio de Janeiro. Ano 13. Volume 20. Número 3. Setembro a Dezembro de 2019

Periódico Quadrimestral da Pós-Graduação Stricto Sensu em Direito Processual da UERJ

Patrono: José Carlos Barbosa Moreira (in mem.). ISSN 1982-7636. pp. 145-186 www.redp.uerj.br

tais medidas caso a presunção de veracidade quanto aos fatos que se pretendia provar não for possível ${ }^{104}$.

Nesse sentido, José Miguel Garcia Medina ${ }^{105}$ aduz que, em caso de incidente processual, aplicam-se o artigo 400, caput, e a Súmula $\mathrm{n}^{\circ} 372$, do STJ, tendo em vista a existência de um processo em curso, o intuito probatório da medida e a possibilidade de aplicação da sanção de confissão. Contudo, possuindo a demanda caráter autônomo e sendo empregada para realizar o direito material à exibição, será inaplicável a Súmula $\mathrm{n}^{\circ}$ 372, do STJ, tendo em vista a ineficácia das sanções que não envolvam medidas coercitivas, diante da inexistência de direito a ser provado, em relação ao qual incidiria a confissão.

Contra o terceiro particular, a redação problemática do CPC/2015 abriu espaço para discussões doutrinárias. O artigo 401, do CPC, prevê que o terceiro possuidor do documento ou coisa será citado, não intimado, o que faz presumir a formação de uma ação incidental ${ }^{106} /$ processo incidente $e^{107}$, autuado em apartado e apenso à ação em curso, e no qual o terceiro irá figurar como parte ré.O artigo 402, do CPC, porém, prevê que o julgamento do procedimento instaurado se dará por decisão, distintamente do artigo 361, do CPC/73, que expressamente estabelecia um julgamento por sentença.

Apegando-se à terminologia literal do artigo 402, do CPC, parte da doutrina considera que a exibição contra terceiro será sempre apreciada como um incidente processual, nos próprios autos do processo em curso, não havendo a "formação de nova relação jurídica processual, nem a instauração de novo processo em apartado"108. A decisão que a julga, assim, possuiria natureza incidental e estaria sujeita a agravo de instrumento.

Sérgio Cruz Arenhart, Luiz Guilherme Marinoni e Daniel Mitidiero, defensores dessa perspectiva, sustentam que "o ato que conclui a exibição de documento ou coisa em

\footnotetext{
${ }^{104}$ CARVAlHO FILHO, João Francisco Liberato de Mattos. Prova Antecipada no Código de Processo Civil Brasileiro.245f. Salvador, 2017. Dissertação (Mestrado em Direito) - Programa de Pós-graduação da Universidade Federal da Bahia (UFBA), p. 147.

${ }^{105}$ MEDINA, José Miguel Garcia. Novo Código de Processo Civil comentado. São Paulo: Editora Revista dos Tribunais, 2017, p. 706.

${ }^{106}$ Ibidem, p. 706.

${ }^{107}$ DIDIER JR., Fredie. Curso de direito processual civil: teoria da prova, direito probatório, decisão, precedente, coisa julgada e tutela provisória. Salvador: Ed. Jus Podivm, 2018, p. 262.

${ }^{108}$ CUNHA, Leonardo Carneiro da; NUNES, Dierle; STRECK, Lenio Luiz (Orgs.). Comentários ao código de processo civil. São Paulo: Saraiva, 2017, p. 612.
} 
Revista Eletrônica de Direito Processual - REDP.

Rio de Janeiro. Ano 13. Volume 20. Número 3. Setembro a Dezembro de 2019

Periódico Quadrimestral da Pós-Graduação Stricto Sensu em Direito Processual da UERJ

Patrono: José Carlos Barbosa Moreira (in mem.). ISSN 1982-7636. pp. 145-186

www.redp.uerj.br

face de terceiro deve ser atualmente visto como decisão interlocutória"109. A posição dos autores se embasa em três argumentos: (i) a literalidade do artigo 402, do CPC; (ii) a hipótese de cabimento de agravo de instrumento contra decisão que examinar pedido de exibição ou posse de documento ou coisa (art. 1.015, VI, CPC); e (iii) a desvantagem prática de, admitindo-se a natureza de sentença, sujeitar a decisão ao efeito suspensivo da apelação, até eventual análise do recurso.

Noutro sentido, alguns autores entendem "que o pedido de exibição contra terceiro exige da parte uma petição inicial, que será autuada em apenso aos autos principais, porque nesse caso será necessária a instauração de uma ação incidental [...] decididas por sentença, recorrível por apelação"110.

A apresentação de petição inicial somente é dispensada nos casos em que o juiz ordenar a exibição de ofício. Ainda assim, porém, haverá uma "ação probatória que instaura uma nova relação processual (NCPC, art. 401)""111.

O termo "citação", contido no artigo 401, do CPC, possuiria maior peso hermenêutico do que a palavra "decisão", contida no artigo de lei subsequente. A justificativa passa pela abrangência semântica das duas palavras. Enquanto "citação" possui um sentido restrito, alusivo ao "ato pelo qual são convocados o réu, o executado ou o interessado para integrar a relação processual" (art. 238, do CPC), “decisão", seguindo a teoria dos atos processuais, pode remeter a três espécies de pronunciamento judicial: (i) despachos; (ii) decisões interlocutórias; e (iii) sentenças.

Assim, corroborando a segunda perspectiva apresentada, entende-se que a exibição em face de terceiro será uma autêntica demanda acessória (art. 61, do CPC), iniciada via petição inicial, incluindo a necessária citação do demandado e encerrando via sentença ${ }^{112}$. Será, portanto, “objeto de apelação, a decisão que, em processo incidental, reconhece a

\footnotetext{
${ }^{109}$ ARENHART, Sérgio Cruz; MARINONI, Luiz Guilherme; MITIDIERO, Daniel. Código de Processo Civil comentado. São Paulo: Thomsom Reuters Brasil, 2018, p. 540.

${ }^{110}$ NEVES, Daniel Amorim Assumpção. Novo Código de Processo Civil Comentado. Salvador: Ed. JusPodivm, 2018, p. 744-745.

${ }^{111}$ FUGA, Augusto Sampaio. Provas no novo CPC: teoria geral das provas. Provas em espécie - inovações e implicações práticas. A teoria do ônus da dinâmico probatório. Novidades da fase instrutória. RVMD, Brasília, V. 9, nº 2, p. 330-362, Jul-Dez, 2015, p. 22-23.

${ }^{112}$ DINAMARCO, Cândido Rangel. Instituições de direito processual civil: volume III. São Paulo: Malheiros, 2017, p. 669.
} 
Revista Eletrônica de Direito Processual - REDP.

Rio de Janeiro. Ano 13. Volume 20. Número 3. Setembro a Dezembro de 2019

Periódico Quadrimestral da Pós-Graduação Stricto Sensu em Direito Processual da UERJ

Patrono: José Carlos Barbosa Moreira (in mem.). ISSN 1982-7636. pp. 145-186 www.redp.uerj.br

obrigação de exibir documentos por parte de terceiro, em face do procedimento especial respectivo, cujo núcleo se estampa no art. 401 do CPC/2015"113.

Finalmente, vale um breve apontamento quanto à sucumbência processual. Diferentemente do procedimento de exibição incidental, no qual a sucumbência acompanha aquela fixada para o desfecho da ação principal em curso, no caso da exibição de documento ou coisa ajuizada em face de terceiro, este será condenado ao pagamento das custas e honorários caso resista injustificadamente à ordem de apresentação. Não havendo resistência, os valores atinentes à sucumbência ficariam a cargo do proponente ${ }^{114}$.

\section{O CONFLITO ENTRE A PRODUÇÃO ANTECIPADA DE PROVAS E A EXIBIÇÃO DE DOCUMENTOS}

$\mathrm{Na}$ esteira dos itens anteriores, a produção antecipada de provas (art. 381 a 383, do CPC) pode ser ajuizada a título de documentação e ciência do demandante, prestando-se a auxiliar na autocomposição das partes.

Caso se pretenda utilizar a prova produzida em outra demanda, esta não deve estar em curso. Estando a ação de conhecimento em curso, dever-se-á produzir a prova dentro do próprio processo, valendo-se da previsão contida no artigo 139, inciso VI, do CPC, e de figuras como o procedimento incidental de exibição de documento ou coisa, nos moldes do artigo 396 a 404, da lei.

Corroborando, o Enunciado n ${ }^{\circ}$ 634, do Fórum Permanente de Processualistas Civis de 2017 (FPPC/2017), dispôs que, na pendência do processo, ocorrendo "a hipótese do art. 381, I ou II, poderá ser antecipado o momento procedimental da prova, seguindo-se o regramento próprio do meio de prova requerido e não o procedimento dos arts. 381 a $383^{\prime \prime 115}$.

Havendo urgência na produção da prova, poder-se-á optar entre o inciso I, do artigo 381, do CPC, e o procedimento previsto nos artigos 305 a 310, do mesmo código, arcando o demandante, neste caso, com a responsabilidade de, uma vez efetivada a tutela cautelar,

\footnotetext{
${ }^{113}$ ALVIM, Arruda. Manual de direito processual civil: teoria do processo e processo de conhecimento. São Paulo: Editora Revista dos Tribunais, 2017, p. 917.

${ }^{114}$ WAMBIER, Teresa Arruda Alvim [et al.]. Primeiros comentários ao novo código de processo civil: artigo por artigo. São Paulo: Editora Revista dos Tribunais, 2016, p. 762.

${ }^{115}$ Disponível em: 〈http://institutodc.com.br/wp-content/uploads/2017/06/FPPC-Carta-de-Florianopolis.pdf>. Acesso em: julho de 2018.
} 
Revista Eletrônica de Direito Processual - REDP.

Rio de Janeiro. Ano 13. Volume 20. Número 3. Setembro a Dezembro de 2019

Periódico Quadrimestral da Pós-Graduação Stricto Sensu em Direito Processual da UERJ

Patrono: José Carlos Barbosa Moreira (in mem.). ISSN 1982-7636. pp. 145-186 www.redp.uerj.br

apresentar o pedido principal em até 30 (trinta) dias (art. 308, do CPC). A doutrina reforça a possível utilização da "medida cautelar requerida de modo antecedente quando o fim seja robustecer ou fundamentar o pedido principal a ser aditado posteriormente" 116 .

Via de regra, caso a parte não apresente o pleito principal dentro do prazo, cessará a eficácia da tutela cautelar concedida (art. 309, inc. I, do CPC). O mesmo se dá quando a tutela cautelar pleiteada não é efetivada em 30 (trinta) dias (inc. II) ou o juiz julga improcedente o pedido principalou extingue a ação sem resolução de mérito (inc. III).

Porém, tratando-se de pedido cautelar de produção de prova com fulcro nos artigos 305 a 310, do CPC, a efetivação da tutela e, consequentemente, o início da contagem do prazo de 30 (trinta) dias para a apresentação do pedido principal, somente se dará quando a prova já estiver produzida e, portanto, a eficácia da cautelar concedida já estiver exaurida.O mesmo ocorre na hipótese do julgamento de improcedência do pedido principal. Nesse sentido, a cessação da eficácia da tutela concedida em caráter antecedente não afetará a prova já produzida (art. 309, inc. I e III, primeira parte, do CPC), mas poderá impedir sua produção cautelar (art. 309, inc. II e III, segunda parte, do CPC).

Resumindo: (i) a produção antecipada de provas (art. 381 a 383, do CPC) e (ii) a produção cautelar de provas requerida em caráter antecedente (art. 305 a 310, do CPC) deverão ser admitidas apenas quando não houver processo de conhecimento em andamento. Havendo, dever-se-á lançar mão de outros institutos, como o da (iii) exibição de documento (art. 396 a 404, do CPC).

Cabe ainda indagar: a antiga cautelar de exibição (arts. 844-845, do CPC/73) foi abarcada pelo instituto da produção antecipada de provas (art. 381 a 383, do CPC) - assim como os institutos do arrolamento de bens e da justificação - ou encontra hoje respaldo no procedimento de exibição de documento ou coisa (art. 396 a 404, do CPC) que permitiria, para além de aplicações incidentais, o ajuizamento de uma ação autônoma de exibição? O ordenamento atual admite a ação autônoma de exibição, ancorada nos artigos 396 a 404, do $\mathrm{CPC}$ ?

A doutrina se divide em três linhas de pensamento, aqui denominadas com referência à natureza que atribuem ao instituto da exibição: (i) teoria incidental; (ii) teoria autônoma; e (iii) teoria autônoma diferenciada.

\footnotetext{
${ }^{116}$ ABELHA, Marcelo. Manual de direito processual civil. Rio de Janeiro: Forense, 2016, p. 582-583.
} 
Revista Eletrônica de Direito Processual - REDP.

Rio de Janeiro. Ano 13. Volume 20. Número 3. Setembro a Dezembro de 2019

Periódico Quadrimestral da Pós-Graduação Stricto Sensu em Direito Processual da UERJ

Patrono: José Carlos Barbosa Moreira (in mem.). ISSN 1982-7636. pp. 145-186 www.redp.uerj.br

A primeira linha, majoritária, entende que a antiga cautelar de exibição é hoje abarcada pela produção antecipada de provas - instituto que admitiria qualquer meio de prova -, reservando ao procedimento de exibição com fulcro nos artigos 396 a 404, do CPC, natureza exclusivamente incidental ${ }^{117}$.

Arenhart, Marinoni e Mitidiero sustentam que a exibição preparatória somente tem lugar por meio da medida de produção antecipada de prova ${ }^{118}$. Nesse sentido, "qualquer prova que deva ser assegurada antes do ajuizamento da demanda em que possa ser empregada deve ser colhida por meio do procedimento descrito nos arts. 381 a 383, CPC" 119 .

O jurista Cassio Scarpinella Bueno segue o mesmo caminho, afirmando somente ser cabível a exibição de documento caso já exista uma ação em curso. Não havendo, "a parte poderá se valer do procedimento previsto no art. 381, do CPC/2015" "120.

Na mesma linha, segue Leonardo Carneiro Cunha, para quem o CPC/2015 “aboliu o procedimento especial cautelar autônomo para a exibição de documento ou coisa (arts. 844 e 845 do CPC/1973)""121. A medida em caráter preparatório somente seria possível por meio do rito da produção antecipada da prova, podendo-se aplicar, no que for compatível, o disposto nos artigos que disciplinam a exibição de documento ou coisa.

O autor Leonardo Carneiro da Cunha pontua que o instituto previsto nos artigos 396 a 404, do CPC, não corresponde às hipóteses em que o pleito se limita à “condenação ao cumprimento de obrigação de fazer consistente na própria exibição de documento ou coisa, caso em que a instrução probatória seria inteiramente voltada à aferição do direito do demandante à exibição"122.

Cesar Cury, debruçando-se sobre os instrumentos destinados à concretização das intenções conciliatórias e cooperativas do código de processo civil, inclui a prova

\footnotetext{
${ }^{117}$ TALAMINI, Eduardo. Produção antecipada de prova no código de processo civil de 2015. Revista de Processo, vol. 260/2016, p. 75 - 101, Out / 2016, p. 08; THEODORO JUNIOR, Humberto. Código de Processo Civil anotado. Rio de Janeiro: Forense, 2018, p. 497; WAMBIER, Teresa Arruda Alvim [et al.]. Primeiros comentários ao novo código de processo civil: artigo por artigo. São Paulo: Editora Revista dos Tribunais, 2016, p. 756.

${ }^{118}$ ARENHART, Sérgio Cruz; MARINONI, Luiz Guilherme; MITIDIERO, Daniel. Novo curso de processo civil: tutela de direitos mediante procedimento comum. São Paulo: Editora Revista dos Tribunais, 2015, p. 347.

${ }^{119}$ ARENHART, Sérgio Cruz; MARINONI, Luiz Guilherme; MITIDIERO, Daniel. Código de Processo Civil comentado. São Paulo: Thomsom Reuters Brasil, 2018, p. 520.

${ }^{120}$ BUENO, Cassio Scarpinella. Comentários ao código de processo civil. São Paulo: Saraiva, 2017, p. 284.

${ }^{121}$ CUNHA, Leonardo Carneiro da; NUNES, Dierle; STRECK, Lenio Luiz (Orgs.). Comentários ao código de processo civil. São Paulo: Saraiva, 2017, p. 608.

${ }^{122}$ Ibidem, 2017, p. 608.
} 
Revista Eletrônica de Direito Processual - REDP.

Rio de Janeiro. Ano 13. Volume 20. Número 3. Setembro a Dezembro de 2019

Periódico Quadrimestral da Pós-Graduação Stricto Sensu em Direito Processual da UERJ

Patrono: José Carlos Barbosa Moreira (in mem.). ISSN 1982-7636. pp. 145-186 www.redp.uerj.br

documental no procedimento de produção antecipada de provas, sustentando ser facultado às partes "a obtenção de documentos e outros dados relevantes por meio da antecipação da produção de prova (art. 381), dando ensejo a melhor visualização e gerenciamento para a autocomposição do conflito"123.

A produção antecipada de provas, assim, abarcaria o exame de quaisquer fontes e a realização de quaisquer meios de prova. "Tanto a prova testemunhal comporta produção antecipada, quanto a pericial, o depoimento pessoal, a inspeção judicial ou mesmo a documental"124, contrastando com o CPC/1973, que, por meio da produção antecipada de provas, somente admitia a antecipação de prova oral ou pericial ${ }^{125}$.

Estariam extintas, portanto, as cautelares nominadas, subsistindo a exibição somente a título incidental ${ }^{126}$.Os institutos da justificação e a exibição de documento teriam perdido sua natureza cautelar e, somadas à produção antecipada de provas, dado origem à ação probatória autônoma ${ }^{127}$.

A teoria autônoma defende, para além da utilização incidental, a possibilidade de uma ação autônoma de exibição fundamentada nos artigos 396 a 404, do CPC. Nesse sentido, toda a vez que a mera exibição constituir o mérito de uma ação principal, de modo que, exibida a coisa, esgote-se o interesse material do autor, haverá uma ação autônoma de exibição ${ }^{128}$.

Arruda Alvim pontua que, da mesma maneira que inexiste previsão expressa de ação autônoma de exibição de documento ou coisa, não há óbice a que referida exibição seja requerida antes do processo principal ${ }^{129}$. Na concepção do autor, é "perfeitamente possível que a exibição satisfaça plenamente o requerente e [...] desaconselhe qualquer providência ulterior" ${ }^{\prime 30}$.

\footnotetext{
${ }^{123}$ CURY, Cesar Felipe. Produção antecipada de prova e disclosure no direito brasileiro. Revista FONAMEC - Rio de Janeiro, v.1, n. 1, p. 111 - 131, maio 2017, p. 121.

${ }^{124}$ DINAMARCO, Cândido Rangel. Instituições de direito processual civil: volume III. São Paulo: Malheiros, 2017, p. 112.

${ }^{125}$ TALAMINI, Eduardo. Produção antecipada de prova no código de processo civil de 2015. Revista de Processo, vol. 260/2016, p. 75 - 101, Out / 2016, p. 06.

${ }^{126}$ MANUCCI, Renato Pessoa. Panorama dos meios de prova no novo CPC. Disponível em: $<$ https://df8aa6jbtsnmo.cloudfront.net/download/Aula\%2007\%20-\%20Direito\%20Processual\%20Civil\%20\%20Leitura.pdf $>$. Acesso em: abril de 2018.

${ }^{127}$ NEVES, Daniel Amorim Assumpção. Manual de direito processual civil. Salvador: JusPodivm, 2018, p. 755.

${ }^{128}$ ABELHA, Marcelo. Manual de direito processual civil. Rio de Janeiro: Forense, 2016, p. 582-583.

${ }^{129}$ ALVIM, Arruda. Manual de direito processual civil: teoria do processo e processo de conhecimento. São Paulo: Editora Revista dos Tribunais, 2017, p. 914.

${ }^{130}$ Ibidem, p. 914.
} 
Revista Eletrônica de Direito Processual - REDP.

Rio de Janeiro. Ano 13. Volume 20. Número 3. Setembro a Dezembro de 2019

Periódico Quadrimestral da Pós-Graduação Stricto Sensu em Direito Processual da UERJ

Patrono: José Carlos Barbosa Moreira (in mem.). ISSN 1982-7636. pp. 145-186 www.redp.uerj.br

José Miguel Garcia Medina categoriza a ação exibitória autônoma como de natureza mandamental, envolvendo a obrigação de fazer. Afirma que a ação se volta exclusivamente à exibição, podendo ser ajuizada "com o intuito de apenas ver a coisa ou documento exibidos, com o intuito de satisfazer direito material à exibição, constante de lei ou de contrato (aplica-se ao caso o disposto nos arts. 497 do CPC/2015, já que exibir é fazer)"131.

Assim, o instituto da exibição de documento possuiria aplicabilidade tripla, ensejando um incidente processual quando formulado no curso do processo de conhecimento e contra a parte contrária; uma ação incidental, quando formulado na pendência do processo de cognição e contra terceiro; e uma ação principal, "com finalidade específica de obtenção de documento ou coisa" ${ }^{132}$.

Por fim, raramente encontrada, porém não menos importante, a terceira perspectiva sustenta que, caso a prova documental já exista e somente precise ser trazida à tona, deverse-á ajuizar uma ação autônoma de exibição (arts. 396 a 404, do CPC). Porém, na hipótese em que a prova precise ser ainda produzida, o procedimento adequado a ser utilizado seria a produção antecipada de provas (art. 381 a 383, do CPC). A despeito da admissão da ação autônoma de exibição, trata-se de uma perspectiva distinta da anterior, apegando-se não ao critério do meio de prova, mas ao aspecto material da prova que se pretende produzir, considerando se esta já existe ou não.

O autor João Francisco Liberato de Mattos Carvalho Filho, partidário dessa teoria, sustenta que, havendo requerimento de exibição de documentos em sede de processo autônomo, dever-se-á utilizar do instituto "constante dos arts. 396 e ss. Apenas seria o caso de utilizar o regramento do art. 381 e ss. se o intuito fosse a produção de provas e não a mera exibição" 133 .

Dentre as três linhas de pensamento abordadas, e este é o objetivo almejado por este artigo, a teoria autônoma aparenta ser a que mais se enquadra nas diretrizes do CPC/2015 que, conforme anteriormente trabalhado, compromete-se com o direito autônomo à prova, a economia processual, a instrumentalidade das formas processuais e a primazia da decisão de mérito.

\footnotetext{
${ }^{131}$ MEDINA, José Miguel Garcia. Novo Código de Processo Civil comentado. São Paulo: Editora Revista dos Tribunais, 2017, p. 703.

${ }^{132}$ CARVALHO FILHO, João Francisco Liberato de Mattos. Prova Antecipada no Código de Processo Civil Brasileiro.245f. Salvador, 2017. Dissertação (Mestrado em Direito) - Programa de Pós-graduação da Universidade Federal da Bahia (UFBA), p. 145-146.

${ }^{133}$ Ibidem, p. 149-150.
} 
Rio de Janeiro. Ano 13. Volume 20. Número 3. Setembro a Dezembro de 2019

Periódico Quadrimestral da Pós-Graduação Stricto Sensu em Direito Processual da UERJ

Patrono: José Carlos Barbosa Moreira (in mem.). ISSN 1982-7636. pp. 145-186 www.redp.uerj.br

Ao passo em que a primeira linha limita injustificadamente as vias processuais acessíveis ao demandante, ignorando a perfeita plausibilidade de uma ação ordinária direcionada à obrigação de exibir (fazer) do demandado, a terceira linha confunde a materialidade da fonte da prova ("são fontes de prova as coisas, as pessoas e os fenômenos" 134 a partir dos quais será a prova produzida) com o caráter iminentemente processual da prova em suas quatro etapas de produção. A prova somente é considerada produzida quando proposta, admitida e produzida em processo, sendo irrelevante que preexista ou não em âmbito material, o que denota o equívoco da distinção entre produção e exibição de prova condicionada à existência prévia do objeto que servirá como fonte de prova, implicando, em todo caso, sua produção.

Em defesa da teoria autônoma, portanto, pode-se inferir que a existência da produção antecipada de provas (arts. 381-404, do CPC), enquanto instituto processual destinado à produção probatória em caráter autônomo e desvinculado de demanda principal de cunho material, não obsta a propositura, seguida do conhecimento e da apreciação por parte do órgão jurisdicional, de petição inicial adequada ao rito ordinário que, almejando a obtenção de uma sentença de caráter mandamental, apresente única e exclusivamente pedido de exibição direcionado à parte demandada.

Para além do substrato processual afeto à instrumentalidade, os direitos à prova (art. $5^{\circ}$, inc. LV, da CF) e à informação (art. $5^{\circ}$, inc. XIV, da CF) constituem a base de direito material da subsistência da ação autônoma de exibição no ordenamento jurídico, reforçada nos casos em que a relação entre as partes se encaixa nos pressupostos de incidência da normativa consumerista, que prevê mais uma série de garantias do direito do consumidor à informação (arts. $6^{\circ}$, inc. III, 20, 31, 35 e 54, §5º todos do CDC).

Frise-se que não se trata de cautelar de exibição, prevista nos artigos 844 e 845, do CPC/73, e extinta pelo CPC/2015, mas de ação autônoma de exibição voltada à satisfação dos direitos subjetivos à prova e informação.

Distintamente da produção antecipada de provas, a ação autônoma de exibição seguirá o rito ordinário, menos célere e sucinto do que aquele previsto nos artigos 381 a 404, do CPC. Almejando-se exclusivamente o acesso à informação, a resistência injustificada da contraparte em cumprir com a ordem deverá ser coibida através das

\footnotetext{
${ }^{134}$ DIDIER JR., Fredie. Curso de direito processual civil: teoria da prova, direito probatório, decisão, precedente, coisa julgada e tutela provisória. Salvador: Ed. Jus Podivm, 2018, p. 53.
} 
Rio de Janeiro. Ano 13. Volume 20. Número 3. Setembro a Dezembro de 2019

Periódico Quadrimestral da Pós-Graduação Stricto Sensu em Direito Processual da UERJ

Patrono: José Carlos Barbosa Moreira (in mem.). ISSN 1982-7636. pp. 145-186 www.redp.uerj.br

medidas coercitivas contidas no artigo 400, parágrafo único, do CPC, tendo em vista que a inocuidade pena de confissão.

Ademais, o procedimento somente será admitido em caráter contencioso e não a título de jurisdição voluntária, tendo em vista a imprescindível observância dos requisitos estabelecidos pelo STJ, quando do julgamento do REsp $\mathrm{n}^{\circ} 1.349 .453 / \mathrm{MS}$, para a demonstração do interesse de agir em procedimentos de exibição. Dentre os requisitos, encontra-se a existência de pretensão resistida em seara administrativa, o que, pelo princípio da eventualidade, na hipótese de procedência do pedido autoral, imporia ao réu o dever de arcar com o valor das custas e honorários.

Caso a razão esteja com essa segunda linha teórica, remanesce o seguinte questionamento: a despeito da existência de uma ação autônoma de exibição a ser manejada sob o regramento dos artigos 396 a 404, do CPC, poder-se-ia pleitear a exibição através da produção antecipada de provas?

Eduardo Cambi, Sandro G. Martins, Paulo d'Arce Martins, Rogéria Dotti e Sandro Kozikoski afirmam que "o processo autônomo de produção antecipada de provas não é adequado para a exibição de documentos ou coisa, dada a previsão de procedimento específico no rol de meios de provas (NCPC, arts. 396-404)"135. Fredie Didier Jr. corrobora, defendendo ser possível "requerer a antecipação da produção de qualquer prova, ressalvada a prova documental, cuja produção antecipada se pede por meio de ação de exibição" ${ }^{" 136}$.

Entretanto, considerando, primeiramente, a maior autonomia conferida às partes pelo novo ordenamento processual e a busca pela resolução do mérito -em detrimento do apego a formalidades processuais desnecessárias - e, em segundo plano, a falta de restrição legal ao procedimento da produção antecipada de provas, entende-se ser também possível o ajuizamento desse tipo de demanda com vistas à exibição de documento ou coisa.O sujeito interessado no cumprimento da ordem de exibição deverá optar pelo instituto que melhor

${ }^{135}$ CAMBI, Eduardo; DOTTI, Rogéria; PINHEIRO, Paulo Eduardo d'Arce; MARTINS, Sandro Gilbert; KOZIKOSKI, Sandro Marcelo. Curso de processo civil completo. São Paulo: Editora Revista dos Tribunais, 2017, p. 713.

${ }^{136}$ DIDIER JR., Fredie. Curso de direito processual civil: teoria da prova, direito probatório, decisão, precedente, coisa julgada e tutela provisória. Salvador: Ed. Jus Podivm, 2018, p. 160. 
Revista Eletrônica de Direito Processual - REDP.

Rio de Janeiro. Ano 13. Volume 20. Número 3. Setembro a Dezembro de 2019

Periódico Quadrimestral da Pós-Graduação Stricto Sensu em Direito Processual da UERJ

Patrono: José Carlos Barbosa Moreira (in mem.). ISSN 1982-7636. pp. 145-186

www.redp.uerj.br

lhe aprouver, sendo possível requerê-la "em sede de produção antecipada de provas ou mesmo como pedido de tutela provisória" ${ }^{137}$.

Conforme já se ensinava na vigência do antigo código, deve-se evitar o "apego excessivo às formas, em descompasso com o processo erigido sobre os pilares da instrumentalidade e do aproveitamento dos atos. Nesta ordem de ideais, a fungibilidade é largamente aceita em diversas situações"138, devendo também ser aplicada entre os institutos aqui estudados.

Recentemente, a $18^{\mathrm{a}}$ Câmara Cível do Tribunal de Justiça do Estado do Paraná (TJPR), em acórdão ${ }^{139}$ proferido sob a relatoria da Juíza Substituta em $2^{\circ}$ Grau Luciane Bortoleto, cassou uma sentença que, diante de ação autônoma de exibição, extinguiu o feito sem resolução de mérito pela não comprovação da pretensão resistida em seara administrativa. No mesmo sentido, decidiram a $12^{\mathrm{a}}$ Câmara Cível ${ }^{140}$ e a $14^{\mathrm{a}}$ Câmara Cível $^{141}$. Ainda que os acórdãos citados tenham se filiado à teoria incidental, entenderam corretamente pela necessidade de, previamente à extinção sem julgamento de mérito por falta de interesse processual, tentar adequar o procedimento ao rito da produção antecipada de provas, que admite jurisdição voluntária, no intuito de atingir maior aproveitamento processual, através da decisão de mérito.

Portanto, diante de ação autônoma de exibição que não preencha os fundamentos determinantes do acórdão exarado no REsp no $1.349 .453 / \mathrm{MS}$, deverá o magistrado determinar a emenda da inicial, para que se adeque o pedido ao rito da produção antecipada de provas (que admite jurisdição voluntária), seguindo o preceito fundamental da economia processual. Caso a parte permaneça inerte, poder-se-á extinguir o feito sem resolução de mérito, por ausência de interesse.

Contudo, estando a demanda adequada aos requisitos do REsp $\mathrm{n}^{\circ}$ 1.349.453/MS, a determinação de emenda à inicial com subsequente extinção do feito baseada na suposta falta de adequação do instrumento processual utilizado pela parte não pode ser admitida.

\footnotetext{
${ }^{137}$ ALVIM, Arruda. Manual de direito processual civil: teoria do processo e processo de conhecimento. São Paulo: Editora Revista dos Tribunais, 2017, p. 914.

${ }^{138}$ GUIMARÃES, Filipe. Medidas probatórias autônomas: panorama atual, experiência estrangeira e as novas possibilidades no direito brasileiro. Revista de Processo, vol. 178/2009, p. 123 - 152, Dez / 2009, p. 10.

${ }^{139}$ (TJPR - 18 $8^{\mathrm{a}}$ C.Cível - 0000619-58.2017.8.16.0083 - Francisco Beltrão - Rel.: Juíza Subst. $2^{\circ} \mathrm{Grau}$ Luciane Bortoleto - J. 11.07.2018).

${ }^{140}$ (TJPR - 12 ${ }^{\mathrm{a}}$ C.Cível - 0003210-61.2015.8.16.0180 - Santa Fé - Rel.: Alexandre Gomes Gonçalves - J. 05.07.2018).

${ }^{141}$ (TJPR - 14 ${ }^{a}$ C.Cível - AC - 1653801-7 - Região Metropolitana de Londrina - Foro Central de Londrina Rel.: Rabello Filho - Unânime - J. 04.07.2018).
} 
Rio de Janeiro. Ano 13. Volume 20. Número 3. Setembro a Dezembro de 2019

Periódico Quadrimestral da Pós-Graduação Stricto Sensu em Direito Processual da UERJ

Patrono: José Carlos Barbosa Moreira (in mem.). ISSN 1982-7636. pp. 145-186 www.redp.uerj.br

Reitera-se o posicionamento aqui defendido, de que tanto a produção antecipada de provas, quanto a ação autônoma de exibição constituem vias processuais adequadas à formulação de pleito exibitório, sendo incorreta a extinção do feito pela simples falta de adequação procedimental da ação interposta.

No mesmo sentido, a $9^{\text {a }}$ Câmara Cível, sob relatoria do Juiz Substituto em $2^{\circ}$ Grau Rafael Vieira de Vasconcellos Pedroso, adotando a teoria autônoma, determinou a anulação de sentença que, fundamentada na suposta inadequação da via processual, extinguiu a ação autônoma de exibição de documento sem resolução de mérito ${ }^{142}$.

Por fim, o Desembargador Lauro Laertes de Oliveira, em feito de sua relatoria julgado pela $16^{\text {a }}$ Câmara Cível do TJPR, aduziu que a proibição do ajuizamento da ação autônoma constitui apego exagerado ao formalismo, "obsta o direito de livre escolha da demanda pelo autor, obstaculiza a prestação da tutela jurisdicional, diretrizes contrárias ao sistema instituído pelo CPC/2015, o qual prevê um feixe de normas processuais civis gerais (CPC, arts. $1^{\circ}$ a 12)" que envolve "o direito da razoável duração do processo, incluída a atividade satisfativa, os princípios da cooperação, da eficiência, da motivação e da autocomposição"143.

\section{CONSIDERAÇÕES FINAIS}

Este artigo buscou debater o papel e a melhor maneira de interpretar e aplicar os institutos processuais envolvidos na produção da prova documental, hodiernamente vigentes no ordenamento jurídico nacional.

Sem a pretensão de esgotar as discussões sobre o tema, foi possível identificar, para além dos aspectos pacificados na doutrina - alusivos à superação das cautelares nominadas e ao surgimento de ações probatórias autônomas -, três linhas de pensamento distintas, no que diz respeito à possibilidade de produção antecipada da prova documental por meio de demanda distinta da ação de produção antecipada de provas.

Dentre elas, optou-se, de maneira fundamentada, por aquela denominada "teoria autônoma", segundo a qual, para além da utilização da ação de produção antecipada de

${ }^{142}$ (TJPR - $9^{a}$ C.Cível - AC - 1706968-6 - Região Metropolitana de Londrina - Foro Central de Londrina Rel.: Rafael Vieira de Vasconcellos Pedroso - Unânime - J. 05.04.2018)

${ }^{143}$ (TJPR - 16 ${ }^{\text {a }}$ C.Cível - 0017508-85.2017.8.16.0019 - Ponta Grossa - Rel.: Lauro Laertes de Oliveira - J. 30.05.2018) 
Revista Eletrônica de Direito Processual - REDP.

Rio de Janeiro. Ano 13. Volume 20. Número 3. Setembro a Dezembro de 2019

Periódico Quadrimestral da Pós-Graduação Stricto Sensu em Direito Processual da UERJ

Patrono: José Carlos Barbosa Moreira (in mem.). ISSN 1982-7636. pp. 145-186

www.redp.uerj.br

provas, seria possível ajuizar ação autônoma de exibição de documento, regida pelo rito ordinário e em atenção aos dispositivos contidos nos artigos 396 a 404, do CPC.

Assim, forma-se um quadro conclusivo, a ser utilizado como guia para o sujeito que pretenda produzir uma prova antecipadamente.

Em primeiro plano, aparece a produção cautelar de provas requerida em caráter antecedente (art. 305 a 310, do CPC), que poderá ser utilizada para a antecipação de prova de qualquer natureza, mas exigirá do demandante a responsabilidade de, uma vez efetivada a tutela cautelar, apresentar o pedido principal dentro do prazo fixado em lei. A sucumbência será arbitrada quando do julgamento da ação principal, ficando as custas da produção a cargo daquele que perder a demanda.

A produção antecipada de provas (art. 381 a 383, do CPC) também se prestará à antecipação de qualquer meio de prova, porém, tendo em vista o caráter autônomo do procedimento, não será necessária a formulação de pedido principal. A pretensão do demandante se limitará à produção da prova, no intuito de ver satisfeito seu direito à prova, podendo o feito assumir natureza voluntária ou contenciosa, ficando a sucumbência condicionada ao caso.

A instrumentalidade processual, somada aos direitos à prova e à informação, permitem vislumbrar a possibilidade de ajuizamento de ação autônoma de exibição, de natureza iminentemente contenciosa, regida pelo rito comum e voltada única e exclusivamente à obtenção de documento cujo fornecimento tenha sido rejeitado em via administrativa. Dever-se-á seguir, no que forem cabíveis, as disposições contidas em artigos 396 a 404, do CPC, sendo decidida, caso procedente, por sentença mandamental, que ordenará ao sucumbente o cumprimento de obrigação de fazer consistente na exibição.

Ressalte-se a virtuosidade operacional e funcional de enxergar a fungibilidade entre os institutos citados, na busca pelo melhor aproveitamento do processo e da máquina estatal destinada à resolução dos litígios.

Por fim, tratando-se de antecipação de prova em caráter incidental, não se poderá lançar mão das ações acima mencionadas, devendo-se alterar a ordem das etapas processuais, valendo-se do artigo 139, inciso VI, do CPC, e aplicar os dispositivos típicos de cada meio de prova.

Espera-se que esta pesquisa sirva para fomentar a discussão e auxilie juristas a atingirem um juízo amadurecido e informado sobre a temática. 


\section{REFERÊNCIAS:}

I Jornada de Direito Processual Civil: enunciados aprovados, Brasília/DF, 24 e 25 de agosto de 2017. - Brasília: Conselho da Justiça Federal, Centro de Estudos Judiciários, 2017.

ABELHA, Marcelo. Manual de direito processual civil. Rio de Janeiro: Forense, 2016.

ALVIM, Arruda. Manual de direito processual civil: teoria do processo e processo de conhecimento. São Paulo: Editora Revista dos Tribunais, 2017.

ARAÚJO, José Aurélio de. Capítulo IV - Procedimento probatório extrajudicial. In: Revista Eletrônica de Direito Processual - REDP. Volume XIII. Periódico da PósGraduação Stricto Sensu em Direito Processual da UERJ.

ARENHART, S; MARINONI, L. Curso de processo civil: processo cautelar. São Paulo: Editora Revista dos Tribunais, 2008.

ARENHART, Sérgio Cruz; MARINONI, Luiz Guilherme; MITIDIERO, Daniel. Novo curso de processo civil: tutela de direitos mediante procedimento comum. São Paulo: Editora Revista dos Tribunais, 2015.

BUENO, Cassio Scarpinella. Comentários ao código de processo civil. São Paulo: Saraiva, 2017.

CAMPOS, Felipe de Almeida; FREITAS, Sérgio Henriques Zandona. O instituto jurídico da prova no direito processual brasileiro. Argumenta JournalLaw , n. 25 - jul/dez, 2016.

CARVAlHO FILHO, João Francisco Liberato de Mattos. Prova Antecipada no Código de Processo Civil Brasileiro. 245f. Salvador, 2017. Dissertação (Mestrado em Direito) - Programa de Pós-graduação da Universidade Federal da Bahia (UFBA).

CUNHA, Leonardo Carneiro da; NUNES, Dierle; STRECK, Lenio Luiz (Orgs.). Comentários ao código de processo civil. São Paulo: Saraiva, 2017.

CURY, Cesar Felipe. Produção antecipada de prova e disclosure no direito brasileiro. Revista FONAMEC - Rio de Janeiro, v.1, n. 1, p. 111 - 131, maio 2017.

DIDIER JR., Fredie. Ações autônomas de produção de provas: produção antecipada de prova e justificação. Revista de processo, vol. 218/2013, p. 13-45, Abr/2013. 
Rio de Janeiro. Ano 13. Volume 20. Número 3. Setembro a Dezembro de 2019

Periódico Quadrimestral da Pós-Graduação Stricto Sensu em Direito Processual da UERJ

Patrono: José Carlos Barbosa Moreira (in mem.). ISSN 1982-7636. pp. 145-186 www.redp.uerj.br

DIDIER JR., Fredie. Curso de direito processual civil: teoria da prova, direito probatório, ações probatórias, decisão, precedente, coisa julgada e antecipação dos efeitos da tutela. Salvador: Ed. JusPodivm, 2018.

DINAMARCO, Cândido Rangel. Instituições de direito processual civil: volume III. São Paulo: Malheiros, 2017.

DOTTI, Rogéria; PINHEIRO, Paulo Eduardo d'Arce; MARTINS, Sandro Gilbert; KOZIKOSKI, Sandro Marcelo. Curso de processo civil completo. São Paulo: Editora Revista dos Tribunais, 2017.

FARIA, Márcio Carvalho; GALVÃO FILHO, Maurício Vasconcelos; HARTMANN, Guilherme Kronemberg; GUEDES, Clarissa Diniz; ARAÚJO, José Aurélio de; SILVA, Franklyn Roger Alves. Anteprojeto do Grupo de Pesquisa "Observatório das Reformas Processuais" Faculdade de Direito da Universidade do Estado do Rio de Janeiro, Revista de Processo, vol. 241/2015, p. 111 - 201, Mar / 2015.

FUGA, Augusto Sampaio. Provas no novo CPC: teoria geral das provas. Provas em espécie - inovações e implicações práticas. A teoria do ônus da dinâmico probatório. Novidades da fase instrutória. RVMD, Brasília, V. 9, nº 2, p. 330-362, Jul-Dez, 2015.

GUIMARÃES, Filipe. Medidas probatórias autônomas: panorama atual, experiência estrangeira e as novas possibilidades no direito brasileiro. Revista de Processo, vol. 178/2009, p. 123 - 152, Dez / 2009.

LAUX, Francisco de Mesquita. Relações entre a antecipação da prova sem o requisito da urgência e a construção de soluções autocompositivas. Revista de Processo, vol. 242/2015, p. 457 - 481, Abr / 2015.

LIPPMANN, Rafael Knorr. A "inédita" tutela do direito material (e autônomo) de acesso à prova. $<$ http://www.emap.com.br/Nucleo\%20de\%20Pesquisas\%20Avancadas\%20da\%20E MAP/>. Acesso em: junho de 2018.

LOURENÇO, Haroldo. O direito probatório no novo CPC. Disponível em: $\langle$ http://haroldolourenco.com.br/artigos/odireitoprobatorio.pdf $>$. Acesso em: junho de 2018.

MANUCCI, Renato Pessoa. Panorama dos meios de prova no novo CPC. Disponível em: $<$ https://df8aa6jbtsnmo.cloudfront.net/download/Aula\%2007\%20- 
Rio de Janeiro. Ano 13. Volume 20. Número 3. Setembro a Dezembro de 2019

Periódico Quadrimestral da Pós-Graduação Stricto Sensu em Direito Processual da UERJ

Patrono: José Carlos Barbosa Moreira (in mem.). ISSN 1982-7636. pp. 145-186 www.redp.uerj.br

\%20Direito\%20Processual\%20Civil\%20-\%20Leitura.pdf>. Acesso em: abril de 2018

MARINONI, Luiz Guilherme; MITIDIERO, Daniel. Código de processo civil comentado artigo por artigo. São Paulo: Editora Revista dos Tribunais, 2008.

MEDINA, José Miguel Garcia. Novo Código de Processo Civil comentado. São Paulo: Editora Revista dos Tribunais, 2017.

MENEZES, Pedro Henrique da Silva; RANGEL, Marco Aurélio Scampini Siqueira. Análise comparativa entre o regime de produção antecipada de provas no projeto do novo CPC brasileiro e o CPC português de 2013. RIDB, Ano 3 (2014), nº 5 .

NEVES, Daniel Amorim Assumpção. Manual de direito processual civil. Salvador: JusPodivm, 2018.

OLIVEIRA, Thiago. A aplicação do art. 806 do CPC na ação cautelar de produção antecipada de prova. 56f. Brasília, 2008, Monografia (Especialização em Direito Processual Civil) - Curso de Pós-Graduação Lato Sensu do Instituto Brasiliense de Direito Público - IDP.

PINHO, Humberto Dalla Bernardina de. Direito processual civil contemporâneo: processo de conhecimento, cautelar, execução e procedimentos especiais. São Paulo: Saraiva Educação, 2018.

ROCHA, José de Moura. Produção antecipada de provas. Revista de Processo, vol. 20/1980, p. 56 - 65, Out - Dez / 1980, Doutrinas Essenciais de Processo Civil, vol. 5, p. $819-830$, Out/2011.

SÁ, Renato Marins de. Manual de direito processual civil. São Paulo: Saraiva Educação, 2018.

SCHIAVI, Mauro. Manual de direito processual do trabalho. São Paulo: LTr, 2016.

SOUSA, Ana Clara Ângelo Teixeira. A produção antecipada de provas no novo CPC como estratégia para uma rápida solução do litígio. Disponível em: $\langle$ http://www.direitoprocessual.org.br/aid=37.html?shop_cat=23\&shop_detail=426 $>$. Acesso em: abril de 2018.

TALAMINI, Eduardo. Produção antecipada de prova no código de processo civil de 2015. Revista de Processo, vol. 260/2016, p. 75 - 101, Out / 2016.

THEODORO JUNIOR, Humberto. Código de Processo Civil anotado. Rio de Janeiro: Forense, 2018. 
Revista Eletrônica de Direito Processual - REDP.

Rio de Janeiro. Ano 13. Volume 20. Número 3. Setembro a Dezembro de 2019

Periódico Quadrimestral da Pós-Graduação Stricto Sensu em Direito Processual da UERJ

Patrono: José Carlos Barbosa Moreira (in mem.). ISSN 1982-7636. pp. 145-186 www.redp.uerj.br

WAMBIER, Luiz Rodrigues. Diretrizes fundamentais do novo CPC. In: WAMBIER, Luiz

Rodrigues; WAMBIER, Teresa Arruda Alvim. Temas Essenciais do Novo CPC: Análise das principais alterações do sistema processual civil brasileiro de acordo com a lei no 13.256/2016. São Paulo: Editora Revista dos Tribunais, 2016.

WAMBIER, Teresa Arruda Alvim (Coord.). Primeiros Comentários ao Novo Código de

Processo Civil: artigo por artigo. São Paulo: Editora Revista dos Tribunais, 2015. 